\title{
Vertical escape tactics and movement potential of orthoconic cephalopods
}

\author{
David Peterman ${ }^{\text {Corresp., }}{ }^{,}$, Kathleen Ritterbush ${ }^{1}$ \\ ${ }^{1}$ Department of Geology and Geophysics, University of Utah, Salt Lake City, Utah, United States \\ Corresponding Author: David Peterman \\ Email address: David.Peterman@utah.edu
}

Measuring locomotion tactics available to ancient sea animals can link functional morphology with evolution and ecology over geologic timescales. Externally-shelled cephalopods are particularly important for their central roles in marine trophic exchanges, but most fossil taxa lack sufficient modern analogues for comparison. In particular, phylogenetically diverse cephalopods produced orthoconic conchs (straight shells) repeatedly through time. Persistent re-evolution of this morphotype suggests that it possesses adaptive value. Practical lateral propulsion is ruled out as an adaptive driver among orthoconic cephalopods due to the stable, vertical orientations of taxa lacking sufficient counterweights. However, this constraint grants the possibility of rapid (or at least efficient) vertical propulsion. We experiment with this form of movement using 3Dprinted models of Baculites compressus, weighted to mimic hydrostatic properties inferred by virtual models. Furthermore, model buoyancy was manipulated to impart simulated thrust within four independent scenarios (Nautilus-like cruising thrust; a similar thrust scaled by the mantle cavity of Sepia; sustained peak Nautilus-like thrust; and passive, slightly negative buoyancy). Each model was monitored underwater with two submerged cameras as they rose/fell over $\sim 2$ meters, and their kinematics were computed with 3D motion tracking. Our results demonstrate that orthocones require very low input thrust for high output in movement and velocity. With Nautilus-like peak thrust, the model reaches velocities of $1.2 \mathrm{~m} / \mathrm{s}$ ( 2.1 body lengths per second) within one second starting from a static initial condition. While cephalopods with orthoconic conchs likely assumed a variety of life habits, these experiments illuminate some first-order constraints. Low hydrodynamic drag inferred by vertical displacement suggests that vertical migration would incur very low metabolic cost. While these cephalopods likely assumed low energy lifestyles day-to-day, they may have had a fighting chance to escape from larger, faster predators by performing quick, upward dodges. The current experiments suggest that orthocones sacrifice horizontal mobility and maneuverability in exchange for highly streamlined, 
1 Vertical escape tactics and movement potential of 2 orthoconic cephalopods

3

\author{
David Joseph Peterman ${ }^{1}$, Kathleen Anita Ritterbush ${ }^{1}$ \\ ${ }^{1}$ Department of Geology and Geophysics, University of Utah, Salt Lake City, Utah, USA \\ Corresponding Author: \\ David J. Peterman ${ }^{1}$ \\ 115, Salt Lake City, UT 84112, USA \\ Email address: David.Peterman@utah.edu
}

\title{
Abstract
}

Measuring locomotion tactics available to ancient sea animals can link functional morphology with evolution and ecology over geologic timescales. Externally-shelled cephalopods are particularly important for their central roles in marine trophic exchanges, but most fossil taxa lack sufficient modern analogues for comparison. In particular, phylogenetically diverse cephalopods produced orthoconic conchs (straight shells) repeatedly through time. Persistent re-evolution of this morphotype suggests that it possesses adaptive value. Practical lateral propulsion is ruled out as an adaptive driver among orthoconic cephalopods due to the stable, vertical orientations of taxa lacking sufficient counterweights. However, this constraint grants the possibility of rapid (or at least efficient) vertical propulsion. We experiment with this form of movement using 3D-printed models of Baculites compressus, weighted to mimic hydrostatic properties inferred by virtual models. Furthermore, model buoyancy was manipulated to impart simulated thrust within four independent scenarios (Nautilus-like cruising thrust; a similar thrust scaled by the mantle cavity of Sepia; sustained peak Nautilus-like thrust; and passive, slightly negative buoyancy). Each model was monitored underwater with two submerged cameras as they rose/fell over $\sim 2$ meters, and their kinematics were computed with 3D motion tracking. Our results demonstrate that orthocones require very low input thrust for high output in movement and velocity. With Nautilus-like peak thrust, the model reaches velocities of $1.2 \mathrm{~m} / \mathrm{s}$ ( 2.1 body lengths per second) within one second starting from a static initial condition. While cephalopods with orthoconic conchs likely assumed a variety of life habits, these experiments illuminate some first-order constraints. Low hydrodynamic drag inferred by vertical displacement suggests that vertical migration would incur very low metabolic cost. While these cephalopods likely assumed low energy lifestyles day-to-day, they may have had a fighting chance to escape from larger, faster predators by performing quick, upward dodges. The current experiments suggest that orthocones sacrifice horizontal mobility and maneuverability in exchange for highly streamlined, vertically-stable, upwardly-motile conchs. 
40

41

42

43

44

45

46

47

48

49

50

51

52

53

54

55

56

57

58

59

60

61

62

63

64

65

66

67

68

69

70

71

72

73

74

75

76

77

78

79

\section{Introduction}

A phylogenetically-diverse array of cephalopod mollusks produced straight conchs (orthocones) throughout geologic time, but their ecological contributions to marine systems are unclear. The evolutionary contexts of these animals are well documented: iconic spiral conchs of nautilids (extant) and ammonoids (extinct) are heavily-derived forms that follow early success by orthocone relatives (Holland, 1987). Orthoconic nautiloids were globally distributed and diverse in the Paleozoic, yielding hundreds of fossil genera (Teichert et al., 1964). A branch of orthocerid nautiloids gave rise to orthoconic bactritoids, and eventually to ammonoids (Erben, 1966; Monnet, Klug, and De Baets, 2015). Evolution of tightly-coiled ammonoid conchs in Early Devonian seas (by increased exogastric curvature; Klug and Korn, 2004; Kröger and Mapes, 2007; Monnet, De Baets, and Klug, 2011) may have radically increased horizontal mobility via hydrostatic and hydrodynamic features (aligning jet thrust to the animal's center of mass while simultaneously improving lateral streamlining; Klug and Korn, 2004). While coiled nautiloids evolved several times throughout the Paleozoic (e.g., mostly within Tarphycerida, Lituitida, Nautilida), the diversity and abundance of coiled ectocochleates relative to orthocones increased during this Devonian nekton revolution (Klug et al., 2010). Yet orthoconic nautiloid lineages commonly persisted until the Late Triassic and rarely into the Early Cretaceous (Doguzhaeva, 1994). Furthermore, orthoconic ammonoids repeatedly originated from planispiral ancestors through the Mesozoic (e.g., heteromorph species within Triassic Choristoceratidae, Jurassic Spiroceratidae, Late Jurassic/Early Cretaceous Bochianitidae, and Cretaceous Baculitidae; Wiedmann, 1969; Wright, Callomon, and Howarth, 1996; Hoffmann et al., 2021). The persistence and intermittent appearance of orthoconic forms suggests that this morphotype retained adaptive value, despite proliferation of planispiral conchs among these animals' contemporaries. However, the adaptive value, functional morphology, and ecology of orthoconic cephalopods are poorly understood. We aim to investigate these properties through hydrostatic and hydrodynamic analyses using the Cretaceous baculitid, Baculites compressus (North America, late Campanian), as a test case.

\section{Hydrostatics of orthoconic cephalopods}

Hydrostatic analyses suggest that orthoconic cephalopods assumed vertical orientations at rest (Trueman, 1941; Westermann, 1977, 1996; Peterman et al., 2019; Peterman, Barton, and Yacobucci, 2019). Mass would be anteriorly distributed near the body chamber (housing the animal's soft body) due to the overlying air-filled chambers (the phragmocone buoyancy apparatus). A static orientation occurs when the total center of mass is vertically aligned under the center of buoyancy (Hoffmann et al., 2015). When these centers are forced out of alignment, a restoring moment proportionate to their separation will act to return them to their static, equilibrium condition (Peterman et al., 2019; Peterman et al., 2020a; Peterman et al., 2020b). Mineral deposits (i.e., cameral and endosiphuncular deposits) common among some Paleozoic nautiloid species would have influenced hydrostatics in some way. These deposits are formed syn vivo (Seuss et al., 2011; Pohl and Klug, 2018; for contrasting views see Mutvei, 2018), very 
80 disparate in structure (Teichert, 1933; Flower, 1955a; Fischer and Teichert, 1969), and help 81 characterize several higher taxa of nautiloids (King and Evans, 2019). Though diverse clades had 82 such mineral deposits in their shells, they have been generally regarded as counterweights that 83 facilitated more horizontal postures in the water column (Schmidt, 1930; Flower, 1955b;

84 Westermann, 1977; Holland, 1987; Crick, 1988; Chamberlain, 1993; Barskov et al., 2008).

85 However, recent studies suggest these counterweights may have altered restoring moments and 86 dynamic conch orientation, while the static orientation would likely remain near vertical 87 (Peterman, Barton, and Yacobucci, 2019). More detailed simulations are required to understand 88 the degree to which these structures reduce hydrostatic stability.

89

90

91

92

93

94

95

96

97

98

99

100

101

102

103

104

105

106

107

108

109

110

111

112

113

114

115

116

117

118

Hydrostatic and hydrodynamic relationships (Peterman et al., 2019; Peterman, Barton, and Yacobucci, 2019) do not readily support interpretations of orthoconic cephalopods as swift horizontal swimmers, akin to extant squid (Tsujita and Westermann, 1988). First, the source of jet thrust (i.e., the hyponome) is aligned vertically with the centers of buoyancy and mass (Peterman et al., 2019), supporting that thrust energy would most efficiently be transmitted into upward vertical movement during jet propulsion. If thrust was applied in a horizontal direction, much energy would be lost to rocking since the source of jet thrust is situated much lower than these two hydrostatic centers (Peterman et al., 2019). Moreover, thrust perpendicular to the long axis of the conch would not be sufficient to orient the animal horizontally (for taxa lacking substantial counterweights; Peterman et al., 2019). These properties strongly constrained how orthoconic cephalopods would have interacted with their surroundings, fed, and evaded predators. The source of thrust relative to the mass distribution and vertically streamlined conch suggest that orthocones were adapted for improved vertical movement potential, but at the expense of horizontal mobility.

\section{Orthoconic cephalopod paleoecology}

Constraining likely locomotory functions for orthoconic cephalopods can lend context to a very diverse range of lineages that flourished throughout the Paleozoic and Mesozoic, and are known from nearly all marine paleoenvironments around the globe (Kennedy and Cobban, 1976; Wright, Callomon, and Howarth, 1996; Kröger and Zhang, 2009; Kröger, Servais, and Zhang, 2009). Orthoconic nautiloids are generally regarded as vertical migrants of the water column and/or demersal based on occurrence data, morphological characters, and taphonomic patterns (Kröger, Servais, and Zhang, 2009). Species recovered from offshore sediments may have migrated vertically through pelagic landscapes of varied photic and oxygen zones; whereas species recovered from more coastal deposits may have remained in the neritic zone where demersal feeding would be available (Kröger, Servais, and Zhang, 2009). This demersal lifestyle of feeding on benthic fauna is traditionally interpreted for orthocones (Frey, 1989; Brett and Walker, 2002; Barskov et al., 2008; Kröger and Zhang, 2009). The remarkable disparity of orthocone conchs (especially siphuncular characteristics; Fischer and Teichert, 1969; Barskov et al., 2008) suggests there were some fundamental and/or nuanced differences in their life habits. 
119 Therefore, either vertical migration or primarily demersal lifestyles are not ruled out in the 120 appropriate settings.

121 Orthoconic ammonoids, in contrast, are generally found in neritic and epicontinental

122

123

124

125

126

127

128

129

130

131

132

133

134

135

136

137

138

139

140

141

142

143

144

145

146

147

148

149

150

151

152

153

154

155

156

157

158

settings (Kennedy and Cobban, 1976; Wright, Callomon, and Howarth, 1996). The depth range of baculitid ammonoids was around 50-100 m based on isotopic analyses of well-preserved shell material (Fatherree, Harries, and Quinn, 1998; Lukeneder et al., 2010; Henderson and Price, 2012; Lukeneder, 2015; Sessa et al., 2015; Landman et al., 2018; Hoffmann et al., 2021). A demersal life habit is generally inferred from these analyses due to their isotopic similarity with the benthos (Landman et al., 2018; Ferguson et al., 2019; Hoffmann et al., 2021). Isotopic studies also suggest that some baculitids spent most of their lives at methane seeps, supporting a somewhat sedentary lifestyle (Landman et al., 2018; Rowe et al., 2020). However, baculitid associations with streamlined midwater swimmers, and occurrences in deposits lacking demersal taxa, suggest that these species could cope with life higher in the water column as well (Tsujita and Westermann, 1998; Landman, Cobban, and Larson, 2012).

Key observations remain that suggest horizontal (or subvertical) modes were adopted by at least some species of orthoconic cephalopods. Life habit can be inferred from color patterns preserved on the conch. While some orthocones had color patterns around the entire circumference, others have patterns restricted to the dorsum, suggesting countershading in a nonvertical orientation (Packard, 1988; Westermann, 1998; Kröger, Servais, and Zhang, 2009; Manda and Turek, 2015). These orientations can be explained by resting the soft body on the benthos (Flower, 1955c) or by the use of active locomotion. The former would require some amount of negative buoyancy and would only provide useful camouflage from above, while the latter would require sustained jet thrust of considerable magnitude in forms with lower hydrostatic stability (i.e., those with cameral or endosiphuncular deposits; Peterman, Barton, and Yacobucci, 2019). Contrasting hydrostatic interpretations, aperture-forward, horizontal movement was inferred for the baculitid ammonoid, Sciponoceras, based on the adoral growth direction of a cirripede attached to the venter (Hauschke, Schöllmann, and Keupp, 2011). Similar growth orientations are observed for epizoans on some nautiloid orthocones as well (Baird et al., 1989).

While a single mode of life should not be invoked for all orthoconic cephalopods, the practical challenges faced during the animals' life can be constrained through empirical studies. The model ammonoid, Baculites compressus, can provide valuable insight for the vertical movement potential and kinematics of this hydrostatically-stable morphotype. The anatomy and propulsive capabilities likely varied within and between ammonoid and nautiloid groups; a wide range of experimental conditions allow broader interpretations for how this common conch morphotype may have functioned. Orthocone conch size, ornamentation, curvature, whorl section anatomy, body chamber proportion, and internal sculpture vary between clades; certain physical properties, too, could progressively differ for taxa with higher disparity from our investigated species. Therefore, we primarily limit our interpretations to orthoconic ammonoids and morphologically-similar nautiloids without substantial conch curvature or internal

Peer) reviewing PDF | (2021:04:60301:2:0:NEW 22 Jun 2021) 
159

160

161

162

163

164

165

166

167

168

169

170

171

172

173

174

175

176

177

178

179

180

181

182

183

184

185

186

187

188

189

190

191

192

193

194

195

196

197

198 counterweights. The ease or difficulty in vertical movement, similar to the behavior observed in extant nautilids (Ward et al., 1984; Ward, 1987; O'Dor et al., 1993; Dunstan, Ward, and Marshall, 2011) is of interest. Furthermore, the conditions required to vertically dodge larger, faster, predators with more speed-efficient modes of locomotion (undulatory vs jet propulsion; Wells and O'Dor, 1986; Anderson and Grosenbaugh, 2005; Neil and Askew, 2018) are explored with a range of predator analogues. An investigation of these capabilities can yield clues regarding the adaptive value of this enigmatic morphotype and its iterative recurrence in the fossil record.

\section{Materials \& Methods}

Three-dimensional motion tracking was performed on physical models of Baculites compressus in order to investigate various hydrodynamic properties of the orthocone morphotype. These models were constructed from the virtual hydrostatic model of Peterman et al. (2019) (Fig. 1A). The exterior portion of this model was isolated in Blender (Blender Online Community, 2017), then a soft body more closely resembling the baculitid reconstruction of Klug, Riegraf, and Lehmann (2012) was fabricated and affixed to the aperture using the same software (Fig. 1B). The coiled embryonic shell (ammonitella) was ignored due to its very small scale ( $\sim 0.7 \mathrm{~mm}$; Landman, 1982). Instead, the model tapers to a point approximately $0.7 \mathrm{~mm}$ in diameter. The Baculites compressus model in the current study was designed to have positive or negative buoyant forces that simulate movement in the vertical directions using similar methods to Peterman et al. (2021a). Each model in the current study was constructed at a size of $57 \mathrm{~cm}$ (from the conch apex to distal ends of the arms). An external 3D model of Baculites compressus is stored in the morphosource.org database (ark:/87602/m4/359359).

\section{Vertical movement scenarios}

Differences between the mass of water displaced and total model mass were computed to equal the forces produced during movement under four different scenarios: (1) Nautilus-like cruising thrust, (2) Nautilus-like cruising thrust scaled by the mantle cavity ratio of extant cuttlefish, (3) sustained maximum Nautilus-like thrust, and (4) slightly negative buoyancy similar to extant Nautilus. For Scenario 1, the thrust of $0.015 \mathrm{~N}$ required for a $73 \mathrm{~g}$ Nautilus to overcome drag at its maximum velocity (Chamberlain, 1987) was scaled by the mass of the water displaced by the current orthocone model (212.209 g) to yield a target thrust value of $0.0436 \mathrm{~N}$. The mass of water displaced is equal to organismal mass, assuming a neutrally buoyant condition. This Nautilus-like thrust was then scaled from the mantle cavity ratio of Nautilus (0.15; Wells and O'Dor, 1991) to the mantle cavity ratio of Sepia $(0.25$; Wells and O'Dor, 1991) yielding a target thrust of $0.0727 \mathrm{~N}$ for Scenario 2. The maximum propulsive thrust for Nautilus is a function of body size (Chamberlain, 1987). For Scenario 3, this maximum thrust was computed by substituting the mass of the Baculites compressus model (212.209 $\mathrm{g}$ ) into the following formula reported by Chamberlain (1987):

$$
\mathrm{T}_{\max }=0.0021(\mathrm{~m})-0.103
$$


199

200

201

202

203

204

205

206

207

208

209

210

211

212

213

214

215

216

217

218

219

220

221

222

223

224

225

226

227

228

229

230

231

232

233

234

235

236

237

238

Where $\mathrm{T}_{\max }$ is the maximum propulsive thrust in Newtons and $\mathrm{m}$ is the organismal mass in grams.

The model for Scenario 4 was made slightly negatively buoyant with a similar magnitude observed in extant Nautilus. Ward and Martin (1978) report residual masses (not relieved by buoyancy) for several wild-caught Nautilus. Focusing on larger individuals from their study $(>300 \mathrm{~g}$ ), the average residual mass was $1.76 \mathrm{~g}$ with an average total mass (including the soft body, conch, and chamber liquid) of $676.6 \mathrm{~g}(\sim 0.26 \%$ of their organismal mass is not relieved by buoyancy). This corresponds to a residual mass of $0.552 \mathrm{~g}$ for the orthocone model. In order to manage error, the model mass for this scenario was lowered by $1 \mathrm{~g}$. The model was then made neutrally buoyant by adding liquid into an anterior chamber with a syringe through a self-healing rubber cap. Once the model no longer sank or rose for $\sim 30$ seconds, it was considered neutrally buoyant. Then the residual mass of $0.5 \mathrm{~g}$ was added with water through the syringe to make the model negatively buoyant according to the computed value. This negatively buoyant scenario was chosen to assess the speed of descent for this vertically-streamlined morphotype, and basic swimming capabilities (e.g., vertical migration, pouncing).

Each target buoyant force depends on the mass of the water displaced by the models, which depends on density. Water density $\left(1.000 \mathrm{~g} / \mathrm{cm}^{3}\right)$ was computed with a calibrated $100 \mathrm{ml}$ pycnometer using water from where the motion tracking experiments were conducted (described below). Water conditions including temperature $\left(\sim 28^{\circ} \mathrm{C}\right)$ and salinity were held constant (or nearly so) for measurements and all experiments.

\section{Baculites compressus model construction}

Each model is composed of three parts (Fig. 1B); air-filled voids, PLA (polylactic acid) plastic, and bismuth counterweights. Bismuth was chosen because of its high density, low melting point, and softness. Since the virtual models of these components are only digital volumes, their densities were determined with a calibrated $100 \mathrm{ml}$ pycnometer to compute their masses. Virtual models of the counterweights were placed anteriorly (within the arm crown) with fixed positions and volumes for each model. After determining an appropriate counterweight volume (and therefore mass) for each model, the volumes of the internal voids were adjusted to yield the proper total mass for each model. The positions of the voids were iteratively altered to maintain the same total model mass, while imparting the same hydrostatic stability index $(0.505)$ and apex-upward orientation inferred from the virtual hydrostatic model (Peterman et al., 2019). The virtual models were considered finished when their hydrostatic stabilities and thrusts matched their target values to the third and fourth decimal places, respectively.

Hydrostatic stability indices were computed from the total center of mass and the center of buoyancy. The center of buoyancy was computed from the model of the exterior interface (i.e., a model of the water displaced). This center and the centers of mass for each material of unique density (air, water, PLA plastic, bismuth counterweight), were computed in MeshLab (Cignoni and Ranzuglia, 2014). The total center of mass was computed with the following formula: 


$$
M=\frac{\sum\left(D * m_{o}\right)}{\sum m_{o}}
$$

240 Where $\mathrm{M}$ is the total center of mass in a principal direction, $\mathrm{D}$ is the center of mass of a single

241

242

243

244

245

246

247

248

249

250

251

252

253

254

255

256

257

258

259

260

261

262

263

264

265

266

267

268

269

270

271

272

273

274

275 object in each principal direction, and $\mathrm{m}_{\mathrm{o}}$ is the mass of any object of unique density. All coordinates are measured relative to the same arbitrary datum placed at the center of the aperture. The hydrostatic stability index $\left(\mathrm{S}_{\mathrm{t}}\right)$ was computed from the following equation (after Okamoto, 1996):

$$
S_{t}=\frac{D_{B M}}{\sqrt[3]{V}}
$$

Where $\mathrm{D}_{\mathrm{BM}}$ is the distance between the center of buoyancy $(\mathrm{B})$ and the center of mass $(\mathrm{M})$, computed with the $3 \mathrm{D}$ theorem of Pythagoras. $\mathrm{V}$ is the organismal volume (equal to the volume of water displaced).

The mass distribution of the PLA plastic required to impart the desired hydrostatic stability index was computed with the following formula:

$$
D_{P L A}=\frac{M\left(m_{P L A}+m_{B i}+m_{\text {air }}+m_{\text {water }}\right)-\left(D_{B i} m_{B i}\right)-\left(D_{\text {air }} m_{\text {air }}\right)-\left(D_{\text {water }} m_{\text {water }}\right)}{\left(m_{P L A}\right)}
$$

Where $\mathrm{D}_{\mathrm{PLA}}$ is the location of the PLA center of mass from the datum in each principle direction. $\mathrm{M}$ is the total center of mass in a particular principle direction, $\mathrm{m}$ is the mass of a model component, and $\mathrm{D}$ is the center of mass of each model component in a particular principle direction. Subscripts denote each model component. Water is present only in the negatively buoyant model ( $1 \mathrm{~g})$.

After each virtual model was completed, they were 3D printed in a vertical orientation with an Ultimaker S5 in four parts (in order to fit within the available print volume). Each part contained a watertight void (Fig. 1B) that was sealed during 3D printing. The model parts were all printed without support material due to their generally low overhang angles $\left(<60^{\circ}\right)$. Each of the four parts were chemically welded together with dichloromethane. High heat silicone molds of the counterweights were cast from 3D prints. The counterweights were cast form these molds by heating bismuth in a casting ladle with a propane torch, and evenly pouring the molten bismuth into the mold. The counterweights were further processed by using a metal file and silicon carbide paper until the desired volume and mass was reached. The counterweight masses slightly differed from their virtual counterparts (from $0.7 \%$ to $5 \%$ different) because they were used to compensate for subtle differences between the virtual and actual masses of the $3 \mathrm{D}$ printed parts. This modification minimized error of the target masses at the expense of error in hydrostatic stabilities. The hydrostatic stability indices of the physical models were recomputed with Equation 3, and all model components (aside from air) were weighed in grams to the third decimal place in order to report error in stability and simulated thrust. Tracking points were painted on the apex and the distal end of the arms for each final model (Fig. 1C) to monitor their position with motion tracking.

\section{Motion tracking experiments}


276

277

278

279

280

281

282

283

284

285

286

287

288

289

290

291

292

293

294

295

296

297

298

299

300

301

302

303

304

305

306

307

308

309

310

311

312

313

314

An underwater camera rig was designed to record video footage of the orthocone models as they rose/fell in the water (Fig. 2A). Experiments were performed in a 2.1-meter-deep section of the crimson lagoon - a 50 meter lap pool at the University of Utah. The skeleton of the rig was constructed with two-inch PVC pipe with custom 3D-printed fittings for two camera mounts. Three steel weights were positioned at each end of the T-shaped rig and rubber mats were wrapped around each section to prevent the rig from slipping on the pool liner. Each camera mount consists of a GoPro Hero 8 Black camera in a waterproof case on top of a waterproof LED light (Fig. 2B). Each camera was oriented with the long axis in the vertical direction for improved field of view. Videos were recorded at 60 frames per second with a linear field of view and $4 \mathrm{~K}$ resolution. Each model was held with extendable tongs until steady, then released for a total of 15 trials for the positively buoyant scenarios, and 8 trials for the negatively buoyant scenario. The relationship between model texture and velocity were assessed by coating the orthocone model with peak Nautilus-like thrust (Scenario 3) with hydrophobic silicone spray and performing an additional 15 trials. Sample video footage for Scenario 3 is stored in an online repository (https://doi.org/10.5281/zenodo.4776924).

Dual video footage was imported into the 3D motion tracking software DLTdv8 (Hedrick, 2008) and semi-automatic tracking was used to mark the pixel locations of each tracking point (apex and arms). A calibration was performed in easyWand5 (Theriault et al., 2014 ) to transform the $2 \mathrm{D}$ pixel coordinates from each video into a single set of $3 \mathrm{D}$ coordinates in meters. The model itself was used for wand calibration, ensuring any $3 \mathrm{D}$ orientation of the model yielded its actual body length $(57 \mathrm{~cm})$. Three-dimensional data points higher in the water column were subject to minor image artifacts from light interacting with the water surface. These distortions, in addition to the increasingly oblique apparent angles of each model, yielded higher error in these regions. Calibrations with standard deviations of less than $2 \mathrm{~cm}$ were considered acceptable. The very fast frame rate (60 fps) caused fluctuations in velocity at lower time steps. This was remediated by using a moving average with a window of 11 time steps for the positively buoyant experiments. No moving average was used on the negatively buoyant experiment because only every $10^{\text {th }}$ frame was used to compute velocity (due to very low velocities and long trial times).

Velocities were computed as a function of time for each model using the calibrated, 3D datapoints:

$$
V_{i}=\frac{\sqrt{\left(x_{i}-x_{i-1}\right)^{2}+\left(y_{i}-y_{i-1}\right)^{2}+\left(z_{i}-z_{i-1}\right)^{2}}}{\left(t_{i}-t_{i-1}\right)}
$$

Where $\mathrm{V}$ and $\mathrm{t}$ are velocity and time, and the subscripts $\mathrm{i}$ and $\mathrm{i}-1$ refer to the current and previous time steps, respectively. The 3D theorem of Pythagoras was used to compute the total distance traveled in any $\mathrm{x}, \mathrm{y}, \mathrm{z}$ direction between time steps (which was mostly vertical). The video frame number was divided by the frame rate ( 59.94 frames per second) to compute time. Time zero for each trial was defined as the moment the release mechanism no longer contacted the model.

The curve fitting toolbox in MATLAB R2020a was used fit the velocity data for each model with an asymptotic equation in the form: 


$$
V_{f i t}=a-a e^{-b t}
$$

316 Where $\mathrm{V}_{\text {fit }}$ is the fit velocity and $\mathrm{t}$ is time. The term " $\mathrm{a}$ " is a coefficient denoting the velocity 317 asymptote (i.e., the maximum velocity estimate given a particular thrust), and $\mathrm{b}$ is a coefficient 318 that governs slope.

319

320

321

322

323

324

325

326

327

328

329

330

331

332

333

334

335

336

337

338

339

340

341

342

343

344

345

346

347

348

349

350

351

352

The relationships between hydrostatic stability and hydrodynamic movement were assessed by computing the maximum angle displaced from the vertical static orientation in any particular direction $\left(\theta_{\mathrm{dv}}\right)$ :

$$
\theta_{d v}=\cos ^{-1}\left(\frac{\left(z_{2}-z_{1}\right)}{\sqrt{\left(x_{2}-x_{1}\right)^{2}+\left(y_{2}-y_{1}\right)^{2}+\left(z_{2}-z_{1}\right)^{2}}}\right)
$$

Where the subscripts 1 and 2 of the $\mathrm{x}, \mathrm{y}$, and $\mathrm{z}$ coordinates refer to the arm and apical tracking points, respectively.

\section{Predator evasion potential}

By knowing how velocity increases from stationary initial conditions (Equation 6), the time it takes to move one body length $\left(t_{b l}\right)$ or half a body length $\left(t_{b l / 2}\right)$ can be computed:

$$
\Delta P=L_{b o d y}=\int_{0}^{t} b l a-a e^{-b t}
$$

When the change in position $(\Delta \mathrm{P})$ is equal to the length of the body ( $\left.\mathrm{L}_{\text {body }} ; 57 \mathrm{~cm}\right), \mathrm{t}_{\mathrm{bl}}$ can be computed by integrating Equation 6 and determining the upper limit of integration. This limit was computed iteratively in MATLAB by increasing $t_{b l}$ until the integrated equation was equal to $\mathrm{L}_{\text {body }}$. For an orthocone to dodge a horizontally moving predator, jetting at the last moment would be ideal for a vertical escape. The minimum distance required (D) to dodge a predator attack at some incident velocity $\left(\mathrm{V}_{\mathrm{p}}\right)$ was computed by multiplying $\mathrm{t}_{\mathrm{bl}}$ or $\mathrm{t}_{\mathrm{bl} / 2}$ by the predator's velocity $\left(\mathrm{V}_{\mathrm{p}}\right)$. Since the critical swimming speeds of extinct animals are difficult to determine, extant marine predators were used as analogues.

\section{Results}

\section{Model hydrostatics and error}

Each of the four orthocone models have the same centers of buoyancy because their external volumes are identical (Table 1). However, the centers of mass for each component of unique density differed in order to maintain a stability index of 0.505 as total mass varied between models (Tables 1 and 2). The mass of the bismuth counterweights slightly differed from their virtual counterparts to compensate for differences in mass between the virtual and physical PLA components. This mass difference reduced error in total mass by sacrificing accuracy in hydrostatic stability (Table 3). The differences in PLA mass were likely a result of differences in bulk density between each of the models. Even with identical slicer settings, the path of the extruder in each layer was slightly different between models, which contributed to error in PLA mass and density. Percent difference of hydrostatic stability and thrust between the virtual and physical models is reported on Table 3.

Peer) reviewing PDF | (2021:04:60301:2:0:NEW 22 Jun 2021) 
353

354

355

356

357

358

359

360

361

362

363

364

365

366

367

368

369

370

371

372

373

374

375

376

377

378

379

380

381

382

383

384

385

386

387

388

389

390

391

392

\section{Motion tracking kinematics}

The upward force on the physical models occurs on the center of buoyancy, not the location of the hyponome. However, this location of applied force is a reasonable assumption for these experiments because perfect upward-vertical thrust is still simulated. Furthermore, the actual source of thrust and the centers of buoyancy and mass are very close to being vertically aligned in living orthoconic cephalopods and in the current models. This alignment would allow thrust to be transmitted into primarily upward translation with little energy lost to rocking.

After releasing the models underwater, they primarily moved in the vertical directions with velocities proportionate to their simulated thrust values. Each of the trials were slightly skewed in the horizontal directions due to weak currents created by removing the release mechanism (Fig. 3). Additionally, the initial angles of some trials were slightly tilted from vertical, causing a few outlier trajectories (see Fig. 3A).

During vertical movement, high hydrostatic stability prevented substantial displacements from vertical orientations (Fig. 4). The tracking points were about two degrees from true vertical in a static setting, and most trials remained under five degrees from vertical. Larger angles of displacement were usually the result of a tilted starting position (see Fig. 4A). The negatively buoyant model underwent larger displacements from vertical only at higher velocities $(\sim-7 \mathrm{~cm} / \mathrm{s})$ and consistently tilted dorsum-upwards.

The velocities between all trials of each positively buoyant model were remarkably similar (Fig. 5A-C). However, the negatively buoyant model (Fig. 5D) was more sensitive to initial conditions (i.e., the subtle motion caused by holding the tongs before and during release) due to the relatively low force acting in the downwards direction. While Equation 6 yields high R-squared values $(>0.97)$, it underpredicts velocities at the start and end of the experiments, and slightly overpredicts velocities in the middle. This equation, however, provides a simple model to estimate orthocone swimming velocities using only a few terms (Table 4) and avoids overfitting the data. The velocity asymptote for each positively buoyant model is reported in Table 4. With sustained peak Nautilus-like thrust, the orthocone model reaches $1.2 \mathrm{~m} / \mathrm{s}$ ( 2.1 body length per second) within one second from a stationary initial condition (Fig. 5C; Table 4). A sustained thrust during this narrow time window is a suitable assumption because it is on par with the propulsive period observed in extant Nautilus ( $\sim 0.62-1.39$ seconds; Chamberlain, 1987). While Equation 6 reports asymptotic velocities, experiments with longer durations (over larger vertical distances) are required to determine the upper velocity limit (when hydrodynamic drag is equal to thrust). Coating the model with hydrophobic silicone yields little difference in velocity during the time window of the experiments (Fig. 5C). However, the velocity asymptote of Equation 6 between the coating and uncoated models yields a difference in $23 \mathrm{~cm} / \mathrm{s}$, suggesting that this asymptote term is very sensitive. The negatively buoyant model is capable of reaching relatively high velocities $(\sim 15 \mathrm{~cm} / \mathrm{s})$ after about 20 seconds of uninterrupted sinking, falling from $<2$ meters. 
393

394

395

396

397

398

399

400

401

402

403

404

405

406

407

408

409

410

411

412

413

414

415

416

417

418

419

420

421

422

423

424

425

426

427

428

429

430

431

432

\section{Modeling vertical escape maneuvers in orthocones}

The time required to move one body length $\left(t_{b l}\right)$ or half a body length $\left(t_{b l / 2}\right)$ under each thrust scenario was computed to determine the minimum distance (D) required to dodge a horizontally moving predator (Tables 4 and 5; Fig. 6). With higher thrust values (e.g., peak Nautilus-like thrust) these cephalopods could potentially thwart predator attacks from some relatively faster predators. A successful dodge, however, depends on predator maneuverability and burst swimming duration (Maresh et al., 2004). If D is much larger than the body length of the predator, it could easily adjust its trajectory in the vertical direction and ultimately catch the relatively slower orthocone.

\section{Discussion}

The modeled ammonoid species, Baculites compressus, provides new context for the swimming capabilities, ecology, and adaptive value of the orthocone morphotype. Maintaining model hydrostatics in a chaotic, real-world setting demonstrates that movement is well constrained despite transient flow conditions surrounding the model (due to model rocking, minor ambient currents, and acceleration from a static initial condition; Figs. 3-5). Aspects of these properties likely varied between orthoconic cephalopods with increasingly different ribbing intensity, curvature, whorl section shape, degree of taper, and size. Furthermore, these cephalopods likely assumed diverse life habits during their $420 \mathrm{Myr}$ intermittent range, inferred by their disparity and occurrences in variable facies (Kennedy and Cobban, 1976; Wright, Callomon, and Howarth, 1996; Kröger, Servais, and Zhang, 2009). However, the present experiments reveal first-order constraints for the ubiquitous representatives of this persistent morphotype. Furthermore, a range of model buoyancies (thrusts) simulate possible modes of locomotion that are relevant to a broad range of orthocone taxa. The vertical movement potential revealed by the current experiments is applied further to model different scenarios involving predator evasion.

\section{Vertical movement potential}

The vertically-streamlined shape of orthoconic cephalopods offers several advantages for movement in the vertical direction. High hydrostatic stability would not have allowed these living cephalopods to considerably deviate from a vertical life habit (Peterman et al., 2019) unless they had sufficient counterweights to reduce stability (i.e., cameral and endosiphuncular deposits of some nautiloids; Peterman, Barton, and Yacobucci, 2019). Stability acts passively and reduces energy expenditure in all ectocochleates cephalopods, regardless of conch morphology. However, the benefits of high stability in orthocones would come at the cost of maneuverability (Weihs, 2002; Fish, Hurley, and Costa, 2003; Webb, 2005; Fish and Holzman, 2019). When thrust is applied in the upward direction, living orthocones would have maintained a vertical orientation with negligible deviation $\left(<8^{\circ}\right.$ resulting from tilted starting positions, but generally $<4^{\circ}$ in the models; Fig. 4). The minor disturbances caused by removing the release mechanism (Fig. 3) demonstrate that slow translation in the horizontal directions can occur from 
433 weak external currents in the water column. This behavior also suggests that horizontal thrust 434 would allow slow horizontal movement, which still could have been functional for the location 435 of a mate or capture of slower prey items. Vertical migration, however, would have been much 436 less expensive due to the vertical streamlining of the conch. Very low input thrust can yield high

437

438

439

440

441

442

443

444

445

446

447

448

449

450

451

452

453

454

455

456

457

458

459

460

461

462

463

464

465

466

467

468

469

470

471

472 velocities relative to other ectocochleates of the same mass (Fig. 5; Tables 3 and 4). If certain orthoconic cephalopods underwent similar vertical migration patterns to extant nautilids (Ward et al., 1984; Ward, 1987; O'Dor et al., 1993; Dunstan, Ward, and Marshall, 2011), they would require lower thrusts than those experimented upon to leisurely rise and fall in the water column. These diurnal vertical movements allow feeding at relatively shallower depths during the night to avoid predation (Dunstan, Ward, and Marshall, 2011; Kaartvedt et al., 1996). This feeding tactic may have been more beneficial for ectocochleates in response to more abundant visual predators after the advent of the Devonian nekton revolution (Klug et al., 2010). For baculitids, there is evidence of both demersal behavior and somewhat higher occupation of the water column (Tsujita and Westermann, 1998; Landman, Cobban, and Larson, 2012; Landman et al., 2018; Rowe et al., 2020). Perhaps these ammonoids were able to assume either of these lifestyles, depending on the taxon or available resources. However, it should be noted that isotope values reported for Baculites (Ferguson et al., 2019) are not comparable to vertical migration ranges recorded in Nautilus shell material (Linzmeier et al., 2016).

A slightly negatively buoyant condition would be easier for the living orthocones to manage (like extant nautilids; Ward and Martin, 1978), and represents the more conservative speculation. The downward-facing soft body may have prevented orthocones from efficiently directing a water jet upward, to counteract positive buoyancy, which may be problematic in the event of shell loss due to predation. This scenario may have been managed by ammonoid orthocones, if their complex septa improved buoyancy regulation (i.e., chamber refilling potential; Daniel et al., 1997; Peterman et al., 2021b). If complex ammonoid sutures (Peterman et al., 2021b) or larger siphuncles in some nautiloids (e.g., actinocerids, endocerids; Kröger, 2003) improved buoyancy management for these lifestyles, perhaps the magnitude of negative buoyancy could be adjusted for improved downward movement. The low metabolic cost of upward movement from reduced hydrodynamic drag would apply to downward movement as well. A very small surplus in mass ( $\sim 0.5 \mathrm{~g}, \sim 0.26 \%$ of organismal mass; Ward and Martin, 1978) would allow orthocones to slowly drift downwards. Without jetting, living orthocones would pick up speed (as high as $15 \mathrm{~cm} / \mathrm{s}$ after 20 seconds for a $57 \mathrm{~cm}$ individual, starting $<2 \mathrm{~m}$ above the seafloor; Fig. 5D). However, if these cephalopods were moving too fast, velocity could be managed by small, periodic jets (i.e., braking). Furthermore, they may have been able to move in the horizontal directions through weak jetting or simply by arranging the positions of the arms. This ability is suggested by the negatively buoyant experiments, which would start tilting toward the dorsum and moving in that direction when the downward velocity reached $\sim 8 \mathrm{~cm} / \mathrm{s}$ (Figs. 3D, $4 \mathrm{D}, 5 \mathrm{D})$. This behavior is likely due to the shape of the whorl section of Baculites compressus, which is wider toward the dorsum and narrower toward the venter (similar to the teardrop-shaped cross-section of an airfoil). This classic shape would have lower pressure differentials with a 
473 rounded leading edge compared to other directions (Maxim, 1896). Therefore, orthocones with 474 whorl sections similar to Baculites compressus may have had a slight drag reduction when 475 moving in the dorsal direction, compared to other lateral directions. Sinking may have provided a 476 low-cost feeding strategy because incident fluid would continuously move toward the mouth 477 (compare Peterman et al., 2021a). The reported growth direction of a cirripede attached to the 478 baculitid, Sciponoceras (Hauschke, Schöllmann, and Keupp, 2011) may have resulted from this 479 direction of movement rather than aperture-forward, horizontal swimming. Similar epizoan 480 growth directions on orthoconic nautiloids (Baird et al., 1989) may indicate that these

481

482

483

484

485

486

487

488

489

490

491

492

493

494

495

496

497

498

499

500

501

502

503

504

505

506

507

508

509

510

511

512 cephalopods frequented this mode of locomotion as well. Slowly sinking toward the benthos may have even qualified as a pounce (especially for early Paleozoic orthocones), catching even slower prey items by surprise (e.g., trilobites, gastropods, other cephalopods, etc.; Alexander, 1986; Landman and Davis, 1988; Frey, 1989; Ebbestad and Peel, 1997; Westermann, 1998; Brett and Walker, 2002; Kröger, 2004, 2011).

\section{Vertical escape tactics of orthoconic cephalopods}

During the $\sim 420 \mathrm{Myr}$ range of orthoconic cephalopods, the predatory landscape changed dramatically. From the Early/Middle Ordovician to the Devonian nekton revolution, large orthocones themselves were the among the dominant predators (Brett and Walker, 2002; Walker and Brett, 2002; Kröger and Zhang, 2009; Kröger, Servais, and Zhang, 2009; Klug et al., 2010). After this event, larger, faster, and speed-efficient, nektic predators would have imposed new pressure on ectocochleate cephalopods (Klug et al., 2010, 2017). These changes are reflected in the evolutionary trend of increased coiling in early ammonoids, and would have continued to influence predator-prey interactions for both persisting nautiloid groups and orthoconic ammonoids at different points in time. The high velocities (among ammonoids) in the experiments (Fig. 5C) suggest that vertical evasion tactics may have been feasible for some orthocones, provided that they have similar propulsive capabilities to modern Nautilus.

Nautiloids and ammonoids likely were eaten by other cephalopods and crustaceans throughout the Paleozoic and Mesozoic (Landman and Waage, 1986; Klug, 2007; Kröger, Servais, and Zhang, 2009; Hoffmann et al., 2019). Reports of predation are scarcer for nautiloids compared to ammonoids, especially regarding orthocones (Mapes and Chaffin, 2003). However, predator-prey interactions can be inferred from specific predators through time. Other cephalopods and large arthropods would have likely assumed higher predatory roles during the early Paleozoic (Kröger, 2004, 2011). After the Devonian nekton revolution began, predation of nautiloids would have intensified from durophagous and piscivorous gnathostome fishes (e.g., placoderms, sharks, and other jawed fishes; Seuss et al., 2011) due to their superior size, maneuverability, and feeding capabilities. After the Devonian mass extinction, sharks, holocephalans, and bony fishes would have served higher-tier predatory roles. Large marine reptiles (e.g., plesiosaurs, ichthyosaurs, mosasaurs, etc.) diversified and were among the dominant components of marine ecosystems during the Mesozoic (Stubbs and Benton, 2016). Orthoconic ammonoids, primarily baculitids in the Cretaceous, have well-documented 
513 paleopathologies. Damage frequently occurs near the aperture at various growth stages (Klinger 514 and Kennedy, 2001; Kennedy, Cobban, and Klinger, 2002), likely resulting from pycnodontid 515 fish, coleoids (Kennedy, Cobban, and Klinger, 2002), and/or crustaceans (Keupp, 2012). Fatal 516 injuries caused by mosasaurs are relatively common for Baculites as well (Kauffman 1990;

517 Westermann, 1996; Tsujita and Westermann, 2001). Quick upward jetting could allow easy 518 escape from a benthic or demersal predator (e.g., crustaceans and some cephalopods). However, 519 thwarting attacks from the relatively quicker nektic predators would require specific escape 520 maneuvers.

521

522

523

524

525

526

527

528

529

530

531

532

533

534

535

536

537

538

539

540

541

542

543

544

545

546

547

548

549

550

551

The likelihood of escape would have increased if a somewhat stationary orthocone waited to jet away from a horizontally moving predator until the last possible moment (Fig. 7A). Otherwise the predator could simply adjust its trajectory and catch up to the slower, vertically moving orthocone (Fig. 7B). Within the time it takes for an orthocone to move some percentage of its body length ( $100 \%$ or $50 \%)$, a successful simulated dodge occurs when the distance between a predator (moving at its maximum velocity) and the orthocone is less than the body length of the predator (Fig. 6; Table 5). The condition was chosen because turning radius generally increases with velocity and body length (Maresh et al., 2004), thus reducing maneuverability and vertical correction. It should be noted that marine predators have greatly diversified in locomotor capabilities and feeding behavior through time (Brett and Walker, 2002; Stubbs and Benton, 2016; Klug et al., 2017), so this approach only represents a very general model. Furthermore, repetitive attacks from predators are not considered. Perhaps a single successful dodge would suffice if neighboring prey were captured instead, or within poorly lit waters. While this approach is simple, it suggests that orthoconic cephalopods had a fighting chance of surviving the attacks of some larger predators (using extant marine predators as analogues). Larger marine predators with similar size and speed to some modern cetaceans and saltwater crocodiles may have been outmaneuvered in some cases (Table 5). However, predators with the speed and maneuverability of modern dolphins or some sharks would have been difficult to evade (Table 5). While many aspects of predation behavior are neglected in this model, it should be noted that the vertical orientation of orthocones may have made it difficult for some vertebrate predators to attack because they would have to rotate their heads or entire bodies $\sim 90^{\circ}$ to bite down on the flanks of the shell. For small, quick, highly maneuverable predators (e.g., pycnodontid fish), perhaps it was more favorable for an orthoconic cephalopod to hide in its shell rather than attempting to vertically escape. Therefore, vertically escaping from larger predators that mark certain death is likely a last resort for orthoconic cephalopods, which normally assume low-energy lifestyles (Chamberlain, 1993; Mutvei, 2002; Rowe et al., 2020; Hoffmann et al., 2021).

\section{Paleoecological interpretations}

The low-cost vertical movement and momentarily rapid escape inferred for orthocones by the current experiments better constrain the ecology of these cephalopods. Existing

Peer) reviewing PDF | (2021:04:60301:2:0:NEW 22 Jun 2021) 
552 morphological and ecological information can be used along with these inferred locomotive

553

554

555

556

557

558

559

560

561

562

563

564

565

566

567

568

569

570

571

572

573

574

575

576

577

578

579

580

581

582

583

584

585

586

587

588

589

590

591

capabilities to better elucidate the life habits of these ubiquitous animals.

The largely unknown soft body characteristics of orthoconic cephalopods could contribute to differences in available thrust and velocities. If the propulsion of ammonoid orthocones is more similar to coleoids (Jacobs and Landman, 1993), closer relatives than nautiloids (Kröger, Vinther, and Fuchs, 2011), they may have been able to produce larger thrusts than the highest thrust value used in the current experiments (peak Nautilus-like thrust). However, it is unknown how confinement of the soft body in a rigid shell would reduce propulsive power compared to coleoids which can hyperinflate their mantle cavities (Anderson and Demont, 2000). Furthermore, the lack of well-preserved soft body material (Klug, Riegraf, and Lehmann, 2012; Klug and Lehmann, 2015; but see Klug et al., 2021) complicates homologization of muscles inferred by scars on the shell (Kennedy, Cobban, and Klinger, 2002; Doguzhaeva and Mapes, 2015) to the musculature of extant coleoids or nautiloids. Therefore, the thrust values in the current study pose a wide range of somewhat conservative thrust estimates for ammonoids. For orthoconic nautiloids (orthocerids, endocerids, and actincocerids, among others), muscle scars are different from those of extant Nautilus and tarphycerids which suggests that certain orthocone clades may have been weaker swimmers compared to coiled nautiloid clades (Mutvei, 2002; King and Evans, 2019). In this case, the Nautilus-like peak thrust of the current experiments may be too liberal. However, the magnitude of propulsive differences due to differences in muscle scar size and extent are unclear in the absence of soft part preservation or modern orthocone analogues.

Though far from orthocone analogues, extant shrimpfish (a.k.a. razorfish) assume downward-facing vertical orientations. However, in contrast to orthoconic cephalopods, they can pitch their bodies into horizontal orientations during swimming due to their comparatively lower hydrostatic stability (Fish and Holzman, 2019). Furthermore, these fish can turn about their longitudinal axis with ease due to their low moments of inertia (Atz, 1962; Fish and Holzman, 2019). While this behavior was not investigated in the current study, this property seems likely for orthocones as well, based on their mass distribution and general shape. However, rather than using various fins, orthocones would be limited to swimming with their arms and hyponome near the aperture (if the soft body morphology permitted), which is likely not as effective. The transverse cross-section of shrimpfish (Fish and Holzman, 2019) is also similar to many baculitid ammonoids (see Larson et al., 1997), which infers drag would be reduced in the dorsal direction. Although this horizontal mode of locomotion in orthocones would not be very efficient due to the higher hydrodynamic drag relative to vertical movement, and their low source of jet thrust (i.e., the thrust angle; Okamoto, 1996; Peterman et al., 2019; Peterman, Mikami, and Inoue, 2020). The vertical orientation of shrimpfish is thought to be associated with camouflage (Fish and Holzman, 2019); a function unlikely for comparatively larger orthocones, and those in habitats lacking structure in which to hide.

Exceptional preservation has been reported more commonly for baculitid ammonoids than any other orthocone (Klug, Riegraf, and Lehmann, 2012; Klug and Lehmann, 2015),

Peer) reviewing PDF | (2021:04:60301:2:0:NEW 22 Jun 2021) 
592 allowing more specific interpretations of their life habit. The preservation of large putative eye

593

594

595

596

597

598

599

600

601

602

603

604

605

606

607

608

609

610

611

612

613

614

615

616

617

618

619

620

621

622

623

624

625

626

627

628

629

630

631

capsules and the presence of lateral sinuses at their apertures suggest enhanced predator detection capabilities (Nilsson et al., 2012). The large ventral rostrum on many baculitid shells may have restricted thrust in the ventral direction, suggesting limited horizontal mobility (unless the hyponome could bend around the rostrum using the lateral sinuses). These features, along with the hydrodynamic properties inferred by the current experiments support a life habit of slowly searching for planktic prey, while maintaining the option for somewhat rapid vertical escape from large predators. For baculitids, this life habit is consistent with well-preserved mouthparts (aptychi and radulae) that support planktivory (Landman, Larson, and Cobban, 2007; Kruta et al., 2009; Kruta et al., 2011). A low energy lifestyle of searching for small, planktic prey can be facilitated by low-cost vertical movement or from relatively sedentary, demersal behavior (e.g., around methane seeps teeming with life; Landman et al., 2018; Rowe et al., 2020).

The vertical motility of orthoconic cephalopods is higher relative to planispiral ammonoids, based on their differences in hydrostatic centers (thrust angle; Okamoto, 1996; Peterman et al., 2019; Peterman, Mikami, and Inoue, 2020) and vertical streamlining (Westermann, 1996). This advantage suggests they could have occupied a distinct niche among ectocochleates. The availability of this niche may reflect suitable ecological opportunities arising from dynamic ecological conditions (e.g., predatory pressure, food resources; Cecca, 1997; Reboulet, Giraud, and Proux, 2005). Similarly, dynamic environmental conditions (e.g., sea level rise, microhabitat availability; Yacobucci, 2015) also drive selection and speciation in ectocochleates, which may have increased the availability of this niche in newly-formed epeiric seas.

Our results offer interpretations for the adaptive value of orthoconic cephalopods and potential evolutionary drivers behind their iterative recurrence in the fossil record. Due to the many uncertainties regarding predator evasion and the putative low-energy lifestyle of orthocones (Chamberlain, 1993; Mutvei, 2002; Rowe et al., 2020; Hoffmann et al., 2021), we suggest their low-cost vertical motility and unique hydrostatic properties to be a primary driver of their evolution and success. While orthocones may have maintained the ability to dodge benthic or nektic predators, these capabilities are likely restricted to taxa without substantial conch curvature. Instead, transitional forms (e.g., cyrtocones; Hoffmann et al., 2021) show gradual changes in hydrostatic properties; static orientations with progressively downwardfacing apertures and thrust angles improved for upward locomotion. These trends throughout orthocone ammonoid evolution are generally the inverse of those observed during ammonoid origination (Klug and Korn, 2004; Kröger and Mapes, 2007; Monnet, De Baets, and Klug, 2011; Monnet, Klug, and De Baets, 2015). Furthermore, these transitional forms would not likely facilitate rapid movement.

Orthocones with a higher degree of morphological disparity from our target species, Baculites compressus, could have progressively differing hydrostatic and hydrodynamic properties that constrained their life habits and swimming capabilities. Conch size, curvature,

Peer) reviewing PDF | (2021:04:60301:2:0:NEW 22 Jun 2021) 
632 whorl section shape, ornamentation, body chamber proportion, and internal characteristics (e.g., $633 \mathrm{septal} /$ siphuncular morphology and counterweights) vary within this morphotype. The fluted

634 flanks of some orthocones and variable whorl section shapes (e.g., B. grandis, B. obtrusus, etc.) 635 could have influenced hydrodynamics in some way. Furthermore, some orthocones are curved 636 (grading into the cyrtocone morphotype), which could pose difficulties in steering rapid, upward 637 maneuvers. In order to understand the roles and consequences of these characteristics, their full 638 spectra would need to be investigated with future experiments. Furthermore, stability-reducing 639 counterweights (Peterman, Barton, and Yacobucci, 2019) in the phragmocones of certain taxa 640 must be investigated further in a dynamic setting to determine their potential influences on 641 posture while swimming.

642

643 Conclusions

644 The high hydrostatic stability of orthoconic cephalopods without cameral deposits

645 (Peterman et al., 2019; Peterman, Barton, and Yacobucci, 2019) would have strictly constrained

646 the life habits of these animals. They would have been confined to vertical orientations without

647 the capacity to substantially modify them. These properties raise questions about the modes of

648 life, functional morphology, and adaptive value of the orthocone morphotype. The

649 hydrodynamics inferred by 3D-printed models of the baculitid, Baculites compressus, suggest

650 that vertical movement was well constrained for orthocones (Figs. 3 and 5). High hydrostatic

651 stability prevents rocking during movement, even with somewhat variable starting angles (Fig.

652 4). It seems orthocones are adapted to both upward-vertical movement through active

653 locomotion and passive downward-vertical movement at very little cost. High velocities relative

654 to other ectocochleates of similar size suggest that low hydrodynamic drag is incurred by

655 movement in the upwards direction. Therefore, these living cephalopods required very low

656 energy to vertically migrate in the water column (probably at velocities lower than those in the

657 current study; Fig. 5). Slight negative buoyancy (like extant nautilids, Ward and Martin, 1978)

658 would have allowed these cephalopods do slowly sink after jet thrust is suspended. This

659 condition would have allowed low-energy movement and feeding for vertical migrants while

660 also providing suitable speeds to pounce on benthic prey from above. While these cephalopods

661 likely assumed low energy lifestyles, Nautilus-like peak thrust would have given orthocones a

662 fighting chance at vertically escaping attacks by larger predators. Although coiled ectocochleate

663 cephalopods flourished from the Devonian to end of the Cretaceous, orthoconic cephalopods

664 retained adaptive value during this time as low-energy vertical migrants, with the potential to

665 serve as periodic escape artists.

666

667 Acknowledgements

668 We appreciate the help of Emma Janusz and Mark Weiss for accommodating our experiments at

669 the University of Utah pool (the Crimson Lagoon). We would also like to thank K. De Baets, B.

670 Kröger, A. Pohle, and R. Lemanis for their thoughtful comments and constructive reviews of the 671 manuscript. 
672

\section{References}

674 Alexander RR. 1986. Resistance to and repair of shell breakage induced by durophages in Late

675

676

677

678

679

680

681

682

683

684

685

686

687

688

689

690

691

692

693

694

695

696

697

698

699

700

701

702

703

704

705

706

707

708

709

710
Ordovician brachiopods. Journal of Paleontology 60: 273-285.

Anderson EJ, Demont ME. 2000. The mechanics of locomotion in the squid Loligo pealei: locomotory function and unsteady hydrodynamics of the jet and intramantle pressure. The Journal of Experimental Biology 203: 2851-2863.

Anderson EJ, Grosenbaugh MA. 2005. Jet flow in steadily swimming adult squid. Journal of Experimental Biology 208: 1124-1146. DOI 10.1242/jeb.01507.

Atz JW. 1962. Does the shrimpfish swim head up or head down? Animal Kingdom 66: 175-179. Baird GC, Brett CE, Frey RC. 1989. Hitchhiking epizoans on orthoconic cephalopods: preliminary review of the evidence and its implications. Senckenbergiana lethaea 69, 439465.

Barskov IS, Boiko MS, Konovalova VA, Leonova TB, Nikolaeva SV. 2008. Cephalopods in the marine ecosystems of the Paleozoic. Paleontological Journal 42: 1-1167. DOI 10.1134/S0031030108110014.

Benga G, Chapman BE, Cox GC, Kuchel PW. 2010. Comparative NMR studies of diffusional water permeability of red blood cells from different species: XVIII platypus (Ornithorhynchus anatinus) and saltwater crocodile (Crocodylus porosus). Cell Biology International 34: 703-708. DOI 10.1042/CBI20090430.

Blender Online Community. 2017. Blender, a 3D modelling and rendering package. Blender Institute, Amsterdam. Available at: http://www.blender.org. Accessed 1 June 2018.

Brett C, Walker S. 2002. Predators and predation in Paleozoic marine environments. Paleontological Society Papers 8: 93-118.

Cecca F. 1997. Late Jurassic and Early Cretaceous uncoiled ammonites: Trophism-related evolutionary processes. Comptes Rendus de l'Académie des Sciences-Series IIA-Earth and Planetary Science, 325: 629-634.

Chamberlain Jr. JA. 1987. Locomotion in Nautilus. In: Saunders, W.B., Landman, N.H., eds. Nautilus - the biology and paleobiology of a living fossils. Springer, Dordrecht, 489-526.

Chamberlain Jr. JA. 1993. Locomotion in ancient seas: constraint and opportunity in cephalopod adaptive design. Geobios 15: 49-61.

Cignoni P, Ranzuglia G. 2014. MeshLab. Version 1.3.3. Visual Computing Lab, Pisa, Italy. Available from: http://meshlab.sourceforge.net/. Accessed 1 August 2018.

Crick RE. 1988. Buoyancy regulation and macroevolution in nautiloid cephalopods. Senckenbergiana lethaea 69: 13-42.

Daniel TL, Helmuth BS, Saunders WB, Ward PD. 1997. Septal complexity in ammonoid cephalopods increased mechanical risk and limited depth. Paleobiology 23: 470-481.

Doguzhaeva LA. 1994. An Early Cretaceous orthocerid cephalopod from north-western Caucasus. Palaeontology 37: 889-899.

Peer] reviewing PDF | (2021:04:60301:2:0:NEW 22 Jun 2021) 
711 Doguzhaeva L, Mapes RH. 2015. The body chamber length variations and muscle and mantle

712

713

714

715

716

717

718

719

720

721

722

723

724

725

726

727

728

729

730

731

732

733

734

735

736

737

738

739

740

741

742

743

744

745

746

747

748

749

750

attachments in ammonoids In: Klug C, Korn D, De Baets K, Kruta I, Mapes RH, eds. Ammonoid Paleobiology: from anatomy to ecology. Topics in Geobiology 43, Springer, Dordrecht. 545-584. DOI 10.1007/978-94-017-9630-9_14.

Dunstan AJ, Ward PD, and Marshall NJ. 2011. Vertical distribution and migration patterns of Nautilus pompilius. PLoS ONE 6: e16311. DOI 10.1371/journal.pone.0016311.

Ebbestad JOR, Peel JS. 1997. Attempted predation and shell repair in Middle and Upper Ordovician gastropods from Sweden. Journal of Paleontology 71: 1047-1060.

Erben HK. 1996. Über den Ürsprung der Ammonoidea. Biological Reviews 41: 641-658. DOI 10.1111/j.1469-185X.1966.tb01626.x.

Fatherree JW, Harries PJ, Quinn TM. 1998. Oxygen and carbon isotopic “dissection” of Baculites compressus (Mollusca: Cephalopoda) from Pierre Shale (Upper Campanian) of South Dakota: implications for paleoenvironmental reconstructions. Palaios 13: 376-385.

Ferguson K, MacLeod KG, Landman NH, Sessa JA. 2019. Evaluating growth and ecology in baculitid and scaphitid ammonites using stable isotope sclerochronology. Palaios 34: $317-$ 329. DOI 10.2110/palo.2019.005.

Fernandez-Waid P, Diez G, Bidaguren I, Izagirre U, Blanco JM, Soto M. 2019. Morphological characterization of hydrodynamic behavior of shortfin mako shark (Isurus oxyrinchus) dorsal fin denticles. Journal of Bionic Engineering 16: 730-741. DOI 10.1007/s42235-019-0059-7.

Fischer AG, Teichert C. 1969. Cameral deposits in cephalopod shells. The University of Kansas Paleontological Contributions 37: 1-37.

Fish FE, Holzman R. 2019. Swimming turned on its head: stability and maneuverability of the shrimpfish (Aeoliscus punctulatus). Integrative Organismal Biology 1: 1-14. DOI 10.1093/iob/obz025.

Fish FE, Hurley J, Costa DP. 2003. Maneuverability by the sea lion, Zalophus californianus: turning performance of an unstable body design. Journal of Experimental Biology 206: 667674.

Flower RH. 1955a. Cameral deposits in orthoconic nautiloids. Geological Magazine 92: 89-103. Flower RH. 1955b. Saltations in nautiloid coiling. Evolution 9: 244-260.

Flower RH. 1955c. Trails and tentacular impressions of orthoconic cephalopods. Journal of Paleontology 29: 857-867.

Frey RC. 1989. Paleoecology of well-preserved nautiloid assemblages from a Late Ordovician shale unit, south-west Ohio. Journal of Paleontology 63: 604-620.

Hauschke N, Schöllmann L, Keupp H. 2011. Oriented attachment of a stalked cirripede on an orthoconic heteromorph ammonite-implications for the swimming position of the latter. Neues Jahrbuch für Geologie und Paläontologie Abhandlungen 202: 199-212. DOI 10.1127/0077-7749/2011/0192.

Hedrick TL. 2008. Software techniques for two- and three- dimensional kinematic measurements of biological and biomimetic systems. Bioinspiration and biomimetics 3: 034001. DOI 10.1088/1748-3182/3/3/034001.

Peer] reviewing PDF | (2021:04:60301:2:0:NEW 22 Jun 2021) 
751

752

753

754

755

756

757

758

759

760

761

762

763

764

765

766

767

768

769

770

771

772

773

774

775

776

777

778

779

780

781

782

783

784

785

786

787

788

789

790

Henderson RA, Price GD. 2012. Paleoenvironment and paleoecology inferred from oxygen and carbon isotopes of subtropical mollusks from the late Cretaceous (Cenomanian) of Bathurst Island, Australia. Palaios 27: 617-626. DOI 10.2110/palo.2011.p11-120r.

Hoffmann R, Lemanis R, Naglik C, Klug C. 2015. Ammonoid buoyancy. In: Klug C, Korn D, De Baets K, Kruta I, Mapes RH, eds. Ammonoid Paleobiology: from anatomy to ecology. Topics in Geobiology 44, Springer, Dordrecht. 613-648. DOI 10.1007/978-94-017-9630$9 \_16$.

Hoffmann R, Stevens K, Keupp H, Simonsen S, Schweigert G. 2019. Regurgitalites - a window into the trophic ecology of fossil cephalopods. Journal of the Geological Society 177: 82102. DOI 10.1144/jgs2019-177.

Hoffmann R, Slattery JS, Kruta I, Linzmeier BJ, Lemanis RE, Mironenko A, Goolaerts S, De Baets K, Peterman DJ, Klug C. 2021. Recent advances in heteromorph ammonoid paleobiology. Biological Reviews 96: 576-610. DOI 10.1111/brv.12669.

Holland CH. 1987. The nautiloid cephalopods: a strange success. Journal of the Geological Society 144: 1-15. DOI 10.1144/gsjgs.144.1.0001.

Kaartvedt S, Melle W, Knutsen T, Skjoldal HR. 1996. Vertical distribution of fish and krill beneath water of varying optical properties. Marine Ecology Progress Series 136: 51-58.

Kauffman EG. 1990. Mosasaur predation on ammonites during the Cretaceous-an evolutionary history. In: Boucot AJ, ed., Evolutionary paleobiology of behavior and coevolution. Elsevier, New York. 184-189.

Kennedy WJ, Cobban WA. 1976. Aspects of ammonite biology, biogeography, and biostratigraphy. Special Papers in Palaeontology No. 17: 94p.

Kennedy WJ, Cobban WA, Klinger HC. 2002. Muscle attachment and mantle-related features in Upper Cretaceous Baculites from the United States Western Interior. Abhandlungen der Geologischen Bundesantstalt Wien 57: 89-112.

Keupp H. 2012. Atlas zur Paläopathologie der Cephalopoden. Berliner paläobiologische Abhandlungen 12: 1-392.

King AH, Evans DH. 2019. High-level classification of the nautiloid cephalopods: a proposal for the revision of the Treatise Part K. Swiss Journal of Palaeontology 138: 65-85. DOI 10.1007/s13358-019-00186-4.

Klinger HC, Kennedy WJ. 2001. Stratigraphic and geographic distribution, phylogenetic trends and general comments on the ammonite family Baculitidae Gill, 1871 (with an annotated list of species referred to the family). Annals of the South African Museum 107: 1-29.

Klug C. 2007. Sublethal injuries in early Devonian cephalopod shells from Morocco. Ata Palaeontologica Polonica 52: 749-759.

Klug C, Korn D. 2004. The origin of ammonoid locomotion. Acta Palaeontologica Polonica 49: 235-242.

Klug C, Lehmann J. 2015. Soft part anatomy of ammonoids: reconstructing the animal based on exceptionally preserved specimens and actualistic comparisons. In: Klug C, Korn D, De Baets K, Kruta I, Mapes RH, eds., Ammonoid paleobiology: from anatomy to ecology: 
791

792

793

794

795

796

797

798

799

800

801

802

803

804

805

806

807

808

809

810

811

812

813

814

815

816

817

818

819

820

821

822

823

824

825

826

827

828

829

Topics in Geobiology 44, Springer, Dordrecht. 515-538. DOI 10.1007/978-94-017-96309_12.

Klug C, Riegraf W, Lehmann J. 2012. Soft-part preservation in heteromorph ammonites from the Cenomanian-Turonian Boundary Even (OAE 2) in the Teutoburger Wald (Germany). Palaeontology 55: 1307-1331. DOI 10.1111/j.1475-4983.2012.01196.x.

Klug C, Kröger B, Kiessling W, Mullins GL, Servais T, Frýda J, Korn D, Turner S. 2010. The Devonian nekton revolution. Lethaia 43: 465-477. 10.1111/j.1502-3931.2009.00206.x.

Klug C, Frey L, Pohle A, De Baets K, Korn D. 2017. Palaeozoic evolution of animal mouthparts. Bulletin of Geosciences 92: 439-442. DOI 10.3140/bull.geosci.1648.

Klug C, Schweigert G, Tischlinger H, Pochmann H. 2021. Fail prey or peculiar necrolysis? Isolated ammonite soft body from the Late Jurassic of Eichstätt (Germany) with complete digestive tract and male reproductive organs. Swiss Journal of Palaeontology 140: 1-14. DOI 10.1186/s13358-020-00215-7.

Kröger B. 2003. The size of the siphuncle in cephalopod evolution. Senckenbergiana lethaea 83: 39-52. DOI 10.1007/BF03043304.

Kröger B. 2004. Large shell injuries in Middle Ordovician Orthocerida (Nautiloidea, Cephalopoda). GFF 126: 311-316.

Kröger B. 2005. Adaptive evolution in Paleozoic coiled cephalopods. Paleobiology 31: 253-268. Kröger B. 2011. Size matters - analysis of shell repair scars in endocerid cephalopods. Fossil Record 14: 109-118.

Kröger B, Mapes RH. 2007. On the origin of bactritoids (Cephalopoda). Paläontologische Zeitschrift 81: 316-327.

Kröger B, Zhang Y. 2009. Pulsed cephalopod diversification during the Ordovician. Palaeogeography, Palaeoclimatology, Palaeoecology 273: 174-183. DOI 10.1016/j.palaeo.2008.12.015.

Kröger B, Servais T, Zhang Y. 2009. The origin and initial rise of pelagic cephalopods in the Ordovician. PLoS ONE 4: e7262. doi:10.1371/journal.pone.0007262.

Kröger B, Vinther J, Fuchs D. 2011. Cephalopod origin and evolution: a congruent picture emerging from fossils, development and molecules. Bioessays 33: 602-613. DOI 10.1002/bies.201100001.

Kruta I, Rouget I, Landman NH, Tanabe K, Cecca F. 2009. Aptychus microstructure in Late Cretaceous Ancyloceratina (Ammonoidea). Lethaia 42: 312-321. DOI 10.1111/j.15023931.2009.00154.x.

Kruta I, Landman N, Rouget I, Cecca F, Tafforeau P. 2011. The role of ammonites in the Mesozoic marine food web revealed by jaw preservation. Science 331: 70-72. DOI 10.1126/science. 1198793.

Landman NH. 1982. Embryonic shells of Baculites. Journal of Paleontology 56: 1235-1241.

Landman NH, Waage KM. 1986. Shell abnormalities in scaphitid ammonites. Lethaia 19: 211224. 
830 Landman NH, Davis RA. 1988. Jaw and crop in an orthoconic nautiloid from the Bear Gulch 831 Limestone (Mississippian, Montana). Memoir - New Mexico Bureau of Mines and Mineral

832 Resources 44: 103-107.

833 Landman NH, Larson NL, Cobban WA. 2007. Jaws and radula of Baculites from the Upper 834 cretaceous (Campanian) of North America. In: Landman NH, Davis RA, Mapes RH, eds., 835 Cephalopods present and past: new insights and fresh perspectives. Springer, Dordrecht. $836 \quad 257-298$.

837 Landman NH, Cobban WA, Larson NL. 2012. Mode of life and habitat of scaphitid ammonites. 838

839 Geobios 45: 87-98. DOI 10.1016/j.geobios.2011.11.006.

Landman NH, Cochran JK, Sovacek M, Larson NL, Garb MP, Brezina J, Witts JD. 2018.

840

841

842

843

844

845

846

847

848

849

850

851

852

853

854

855

856

857

858

859

860

861

862

863

864

865

866

867

868

869 Isotope sclerochronology of ammonites (Baculites compressus) from methane seep and nonseep sites in the Late Cretaceous Western Interior Seaway, USA: Implications for ammonite habitat and mode of life. American Journal of Science 318: 603-639. DOI 10.2475/06.2018.01.

Lindgren J, Caldwell MW, Konishi T, Chiappe LM. 2010. Convergent evolution in aquatic tetrapods: insights from an exceptional fossil mosasaur. PLoS ONE 5:e11998. DOI 10.1371/journal.pone.0011998.

Linzmeier BJ, Kozdon R, Peters SE, Valley JW. 2016. Oxygen isotope variability within Nautilus shell growth bands. PLoS ONE 11: e0153890. DOI 10.1371/journal.pone.0153890.

Lukeneder A. 2015. Ammonoid habitats and life history. In: Klug C, Korn D, De Baets K, Kruta I, Mapes RH, eds. Ammonoid Paleobiology: from macroevolution to paleogeography. Topics in Geobiology 44, Springer, Dordrecht. 689-791. DOI 10.1007/978-94-017-9630-9_18.

Lukeneder A, Harzhauser M, Müllegger S, Piller WE. 2010. Ontogeny and habitat change in Mesozoic cephalopods revealed by stable isotopes $\left(\delta^{18} \mathrm{O}, \delta^{13} \mathrm{C}\right)$. Earth and Planetary Science 296: 103-114. DOI 10.1016/j.eps1.2010.04.053.

Manda S, Turek V. 2015. Colour patterns on Silurian orthocerid and pseudorthocerid conchs from Gotland - palaeoecological implications. Estonian Journal of Earth Sciences 64: 74-79. DOI 10.3176/earth.2015.13.

Mapes RH, Chaffin DT. 2003. Predation on Cephalopods. In: Kelley P.H., Kowalewski M., Hansen T.A. (eds) Predator - Prey Interactions in the Fossil Record. Topics in Geobiology, vol 20. Springer, Boston, DOI 10.1007/978-1-4615-0161-9_8.

Maresh JL, Fish FE, Nowacek DP, Nowacek SM. 2004. High performance turning capabilities during foraging by bottlenose dolphins (Tursiops truncatus). Marine Mammal Science 20: 498-509.

Maxim, HS. 1896. Natural and artificial flight. The Aeronautical Annual (Boston).

Monnet C, De Baets K, Klug C. 2011. Parallel evolution controlled by adaptation and covariation in ammonoid cephalopods. BMC Evolutionary Biology 11: 1-21. DOI 10.1186/1471-2148-11-115.

Monnet C, Klug C, De Baets K. 2015. Evolutionary patterns of ammonoids: phenotypic trends, convergence, and parallel evolution. In: Klug C, Korn D, De Baets K, Kruta I, Mapes RH, 
870

871

872

873

874

875

876

877

878

879

880

881

882

883

884

885

886

887

888

889

890

891

892

893

894

895

896

897

898

899

900

901

902

903

904

905

906

907

908

eds. Ammonoid Paleobiology: from macroevolution to paleogeography. Topics in Geobiology 44, Springer, Dordrecht. 95-142. DOI 10.1007/978-94-017-9633-0_5.

Motani R. 2002. Swimming speed estimation of extinct marine reptiles: energetic approach revisited. Paleobiology 28: 251-262.

Mutvei H. 2002. Connecting ring structure and its significance for classification of the orthocerid cephalopods. Acta Palaeontologica Polonica 47: 157-168.

Mutvei H. 2018. Cameral deposits in Paleozoic cephalopods. GFF 140: 254-263. DOI 10.1080/11035897.2018.1483966.

Neil TR, Askew GN. 2018. Swimming mechanics and propulsive efficiency in the chambered nautilus. Royal Society Open Science 5: 170467. DOI 10.1098/rsoc.170467.

Nilsson DE, Warrant EJ, Johnsen S, Hanlon R, Shashar N. 2012. A unique advantage for giant eyes in giant squid. Current Biology 22: 683-688. DOI 10.1016/j.cub.2012.02.031.

O’Dor RK, Forsythe J, Webber DM, Wells J, Wells MJ. 1993. Activity levels of Nautilus in the wild. Nature 362: 626-628.

Okamoto, T. 1996. Theoretical modeling of ammonoid morphology. In: Landman NH, Tanabe K, and Davis RA (eds.), Ammonoid Paleobiology. Topics in Geobiology 13. Plenum, New York. p. 225-251.

Packard A. 1988. Visual tactics and evolutionary strategies. In: Wiedmann J, Kullmann J, eds., Cephalopods - Present and Past. Schweizerbart'sche, Stuttgart. 89-103.

Peterman DJ, Ciampaglio C, Shell RC, Yacobucci MM. 2019. Mode of life and hydrostatic stability of orthoconic ectocochleate cephalopods: hydrodynamic analyses of restoring moments from 3D-printed, neutrally buoyant models of a baculite. Acta Palaeontologica Polonica 64: 441-460. DOI 10.4202/app.00595.2019.

Peterman DJ, Barton CC, Yacobucci MM. 2019. The hydrostatics of Paleozoic ectocochleate cephalopods (Nautiloidea and Endoceratoidea) with implications for modes of life and early colonization of the pelagic zone. Palaeontologia Electronica 22.2.27A: 1-29. DOI $10.26879 / 884$.

Peterman DJ, Mikami T, Inoue S. 2020. The balancing act of Nipponites mirabilis (Nostoceratidae, Ammonoidea): managing hydrostatics throughout a complex ontogeny. PLoS ONE 15: e0235180. DOI 10.1371/journal.pone.0235180.

Peterman DJ, Hebdon N., Ciampaglio CN, Yacobucci MM, Landman NH, Linn T. 2020a. Syn vivo hydrostatic and hydrodynamic properties of scaphitid ammonoids from the U.S. Western Interior. Geobios 60: 79-98. DOI 10.1016/j.geobios.2020.04.004.

Peterman DJ, Shell RC, Ciampaglio CN, Yacobucci MM. 2020b. Sable hooks: biomechanics of heteromorph ammonoids with U-shaped body chambers. Journal of Molluscan Studies 86: 267-279. DOI 10.1093/mollus/eyaa018.

Peterman DJ, Hebdon N, Shell RC, Ritterbush A. 2021a. Twirling torticones: hydrostatics and hydrodynamics of helically-coiled ammonoids. In: Slattery JS, Larson NL, Bingle-Davis M., Graham, FC. eds. Insights into the Cretaceous: Building on the Legacy of William A.

PeerJ reviewing PDF | (2021:04:60301:2:0:NEW 22 Jun 2021) 
909

910

911

912

913

914

915

916

917

918

919

920

921

922

923

924

925

926

927

928

929

930

931

932

933

934

935

936

937

938

939

940

941

942

943

944

945

946

947

Cobban (1916-2015), American Association of Petroleum Geologists and Wyoming Geological Association Special Volume, forthcoming.

Peterman DJ, Ritterbush KA, Ciampaglio CN, Johnson EH, Inoue S, Mikami T, Linn TJ. 2021 b. Complex shell architecture refined buoyancy control in ammonoid cephalopods. Scientific Reports 11: 8055. DOI 10.1038/s41598-021-87379-5.

Pohle A, Klug C. 2018. Early and Middle Devonian cephalopods from Hamar Laghdad (Tafialt, Morocco) and remarks on epicoles and cameral deposits. Neues Jahrbuch für Geologie und Paläontologie Abhandlungen 290: 203-240. DOI 10.1127/njgpa/2018/0776.

Reboulet S, Giraud F, Proux O. 2005. Ammonoid abundance variations related to changes in trophic conditions across the Oceanic Anoxic Event 1d (Latest Albian, SE France). Palaios 20: 121-141.

Rowe AJ, Landman NH, Cochran JK, Witts JD, Garb MP. 2020. Late Cretaceous methane seeps as habitats for newly hatched ammonites. Palaios 35: 151-163. DOI 10.2110/palo.2019.105. Schmidt H. 1930. Über die Bewegungsweise der Schalencephalopoden. Paläontologische Zeitschrift 12: 194-208 [in German].

Segre PS, Potvin J, Cade DE, Calambokidis J, Clemente JD, Fish FE, Fridlaender AS, Gough WT, Kahane-Rapport SR, Oliveira C, Parks SE, Penry GS, Simon M, Stimpert AK, Wiley DN, Bierlich KC, Madsen PT, Goldbogen JA. 2020. Energetic and physical limitations on the breaching performance of large whales. eLife 9: e51760. DOI 10.7554/eLife.51760.

Sessa JA, Larina E, Knoll K, Garb M, Cochran JK, Huber BT, MacLeod KG, Landman NH. 2015. Ammonite habitat revealed via isotopic composition and comparisons with cooccurring benthic and planktonic organisms. PNAS 112: 15562-15567. DOI 10.1073/pnas.1507554112.

Seuss B, Mapes RH, Klug C, Nützel A. 2011. Exceptional cameral deposits in a sublethally injured Carboniferous orthoconic nautiloid from the Buckhorn Asphalt Lagerstätte in Oklahoma, USA. Acta Palaeontologica Polonica, 57: 375-390. DOI 10.4202/app.2011.0008.

Stubbs TL, Benton MJ. 2016. Ecomorphological diversifications of Mesozoic marine reptiles: the roles of ecological opportunity and extinction. Paleobiology 42: 547-573. DOI 10.1017/pab.2016.15.

Tanaka H, Li G, Uchida Y, Nakamura M, Ikeda T, Liu H. 2019. Measurement of time-varying kinematics of a dolphin in burst accelerating swimming. PLoS ONE 14: e0210860. DOI 10.1371/journal.pone.0210860.

Teichert C. 1933. Der Bau der actinoceroiden Cephalopoden. Palaeontographica A 78, 111-230 [in German].

Teichert C, Kummel B, Sweet WC, Stenzel HB, Furnish WM, Glenister BF, Erben HK, Moore RC, Zeller DE. 1964. Part K, Mollusca 3, Cephalopoda - General Features, Endoceratoidea, Actinoceratoidea, Nautiloidea, Bactritoidea. In: Moore, R.C., ed. Treatise on Invertebrate Paleontology. Geological Society of America and The University of Kansas Press, Boulder. 519 p.

Peer) reviewing PDF | (2021:04:60301:2:0:NEW 22 Jun 2021) 
948 Theriault DH, Fuller NW, Jackson BE, Bluhm E, Evangelista D, Wu Z, Betke M, Hedrick TL. 949 2014. A protocol and calibration method for accurate multi-camera field videography. The 950 Journal of Experimental Biology 217: 1843-1848. DOI 10.1242/jeb.100529.

951

952

953

954

955

956

957

958

959

960

961

962

963

964

965

966

967

968

969

970

971

972

973

974

975

976

977

978

979

980

981

982

983

984

985

986

987

Trueman AE. 1941. The ammonite body chamber, with special reference to the buoyancy and mode of life of the living ammonite. Quarterly Journal of the Geological Society 384: 339383.

Tsujita CJ, Westermann GEG. 1998. Ammonoid habitats and habits in the Western Interior Seaway: a case study from the Upper Cretaceous Bearpaw Formation of southern Alberta, Canada. Palaeogeography, Palaeoclimatology, Palaeoecology 144: 135-160.

Tsujita CJ, Westermann GEG. 2001. Were limpets or mosasaurs responsible for perforations in the ammonite Placenticeras? Palaeogeography, Palaeoclimatology, Palaeoecology 169: 245270.

Walker SE, Brett CE. 2002. Post-Paleozoic patterns in marine predation: was there a Mesozoic and Cenozoic marine predatory revolution? Paleontological Society Papers 8: 119-194.

Ward PD, Martin A. 1978. On the buoyancy of the Pearly Nautilus. Journal of Experimental Zoology 205: 5-12. DOI 10.1002/jez.1402050103

Ward PD. 1987. The natural history of Nautilus. Allen and Unwin, Winchester. 267 p.

Ward PD, Carlson B, Weekly M, Brumbaugh B. 1984. Remote telemetry of daily vertical and horizontal movement of Nautilus in Palau. Nature 309: 248-250.

Webb PW. 2005. Stability and maneuverability. In: Shadwick RE, Lauder GV (eds.), Fish Physiology, Fish Biomechanics Vol. 23, Academic Press, p. 281-332.

Webber DM, O'Dor RK. 1986. Monitoring the metabolic rate and activity of free-swimming squid with telemetered jet pressure. Journal of Experimental Biology 126: 205-224.

Weihs D. 2002. Stability versus maneuverability in aquatic locomotion. Integrative and Comparative Biology 42: 127-134. DOI 10.1093/icb/42.1.127.

Wells MJ, O'Dor RK. 1991. Jet propulsion and the evolution of the cephalopods. Bulletin of Marine Science 49: 419-432.

Westermann GEG. 1977. Form and function of orthocone cephalopod shells with concave septa. Paleobiology 3: 300-321.

Westermann GEG. 1996. Ammonoid life and habitat. In: Landman NH, Tabane K, Davis RA, eds., Ammonoid Paleobiology. Plenum, New York. 607-707.

Westermann GEG. 1998. Life habits of nautiloids. In: Savazzi, ed., Functional Morphology of the Invertebrate Skeleton. John Wiley \& Sons, Chichester, New York. 263-298.

Wiedmann J. 1969. The heteromorphs and ammonoid extinction. Biological Reviews 44: 463602.

Wright CW, Callomon JH, Howarth MK. 1996. Part L Mollusca 4 Revised, Vol. 4: Cretaceous Ammonoidea. In: Moore, R.C., ed. Treatise on Invertebrate Paleontology. Geological Society of America and The University of Kansas Press, Boulder. 362 p.

Yacobucci MM. 2015. Macroevolution and Paleobiogeography of Jurassic-Cretaceous Ammonoids. In: Klug C, Korn D, De Baets K, Kruta I, Mapes RH, eds. Ammonoid

PeerJ reviewing PDF | (2021:04:60301:2:0:NEW 22 Jun 2021) 
988

989

990

991

992

993

994

995

996

997

998

999

1000

1001

1002

1003

1004

1005

1006

1007

1008

1009

1010

1011

1012

1013

1014

1015

1016

1017

1018

1019

1020

1021

1022

1023

1024

1025

1026

Paleobiology: from macroevolution to paleogeography. Topics in Geobiology 44, Springer, Dordrecht. 189-228.

\section{Figure and Table Captions}

Figure 1: Construction of a physical, 3D-printed model of Baculites compressus from a virtual hydrostatic model. A) Virtual model used to determine hydrostatic properties (modified from Peterman et al., 2019). B) Virtual model with simplified internal geometry that allows for 3D printing. The total model mass was manipulated to impart an upward buoyant force, simulating downward thrust. The total center of mass (m) relative to the center of buoyancy (b) was maintained with an adorally placed counterweight and various internal voids. C) Physical, 3Dprinted model with tracking points placed at the distal ends of the arms and apex used for 3D motion tracking.

Figure 2: Underwater camera rig used for 3D motion tracking. A) Schematic of the camera rig relative to the model (yellow) and release mechanism (green). The rig was made strongly negatively buoyant with three steel counterweights at the ends (purple). The wireframe shapes radiating from the cameras denote the approximate field of view. B) Close-up view of waterproof camera and LED light with custom, 3D-printed attachments.

Figure 3: Three-dimensional positions from a common starting point for each model through time. A) Scenario 1: Nautilus-like cruising thrust. B) Scenario 2: Nautilus-like cruising thrust scaled by the higher mantle cavity ratio of Sepia. C) Scenario 3: Nautilus-like peak thrust. D) Scenario 4: slightly negatively buoyant ( $\sim 0.26 \%$ of mass not relieved by buoyancy).

Figure 4: Maximum displacement angle in any direction from the vertical axis through time. Each trial is distinguished by color. A) Scenario 1: Nautilus-like cruising thrust. B) Scenario 2: Nautilus-like cruising thrust scaled by the higher mantle cavity ratio of Sepia. C) Scenario 3: Nautilus-like peak thrust. D) Scenario 4: slightly negatively buoyant ( $\sim 0.26 \%$ of mass not relieved by buoyancy).

Figure 5: Velocity in the direction of movement as a function of time. All trials are fit with an asymptote equation. A) Scenario 1: Nautilus-like cruising thrust. B) Scenario 2: Nautilus-like cruising thrust scaled by the higher mantle cavity ratio of Sepia. C) Scenario 3: Nautilus-like peak thrust. A hydrophobic coating was applied to the original model to compare the influence of surface texture and friction drag. D) Scenario 4 : slightly negatively buoyant $(\sim 0.26 \%$ of mass not relieved by buoyancy). 
1027 Figure 6: Diagram of vertical predator escape and related terms. The time required to move one
1028 body length $\left(t_{b l}\right)$ or half a body length $\left(t_{b / 2}\right)$ was computed for each velocity profile (V; Fig. 5).

1028

1029

1030

1031

1032

1033

1034

1035

1036

1037

1038

1039

1040

1041

1042

1043

1044

1045

1046

1047

1048

1049

1050

1051

1052

1053

1054

1055

1056

1057

1058

1059

1060

1061

1062

1063

1064

1065

1066 This time was multiplied by the velocity of various predators $\left(\mathrm{V}_{\mathrm{p}}\right)$ to compute the minimum distance required to start jetting (D). A dodge was considered successful if $D$ is less than the length of the predator $\left(\mathrm{L}_{\mathrm{p}}\right)$. The image of the mosasaur (Platecarpus) was created from the outline inferred by Lindgren et al. (2010).

Figure 7: Scenarios involving successful dodging (A) and unsuccessful dodging (B). The cruising predator first notices the prey (i), then begins to accelerate (ii). After closing in (iii), the predator makes its final lunge for the prey (iv). Cones surrounding the predator indicate hypothetical turning radiuses. For a successful dodge, the orthocone cephalopod must wait until the last possible moment or else the incoming predator could adjust its vertical trajectory. The image of the mosasaur (Platecarpus) was created from the outline inferred by Lindgren et al. (2010).

Table 1: Local centers of mass for the model components (PLA plastic and bismuth counterweight), and total centers of mass and buoyancy for each model (1: Nautilus-like cruising thrust; 2: Nautilus-like cruising thrust scaled by the higher mantle cavity ratio of Sepia; 3: Nautilus-like peak thrust; 4: Slightly negatively buoyant). Only the $\mathrm{x}$ and $\mathrm{z}$ values are reported because the virtual model is perfectly symmetrical. All coordinates are measured relative to the same arbitrary datum (located in the center of the aperture).

Table 2: Masses (m) and volumes (V) for the virtual and physical model components. 1: Nautilus-like cruising thrust; 2: Nautilus-like cruising thrust scaled by the higher mantle cavity ratio of Sepia; 3: Nautilus-like peak thrust; 4: Slightly negatively buoyant. PLA $=3$ D printed plastic; $\mathrm{Bi}=$ bismuth counterweight; $\mathrm{wd}=$ water displaced; Mass def. = mass deficiency required to impart the computed buoyant forces (Table 3); glue $=$ the cyanoacrylate glue used to secure each counterweight. The residual mass in the negatively buoyant experiment (denoted with *) was not weighed, but rather its volume was inserted into the model with a syringe $\left(\sim 0.5 \mathrm{~cm}^{3}\right)$.

Table 3: Virtual and actual hydrostatic stabilities $\left(\mathrm{S}_{\mathrm{t}}\right)$ and thrusts $(\mathrm{F})$, and computed percent errors. 1: Nautilus-like cruising thrust; 2: Nautilus-like cruising thrust scaled by the higher mantle cavity ratio of Sepia; 3: Nautilus-like peak thrust; 4: Slightly negatively buoyant.

Table 4: Velocities, travel times, and asymptote equation coefficients. Uncertainty reflects bounds of $95 \%$ confidence intervals. The asymptotic velocity $(\mathrm{in} \mathrm{cm} / \mathrm{s})$ is predicted by coefficient "a" of Equation 6. Coefficient " $b$ " governs the slope. The maximum body lengths per second (Max. bl/s) were computed by dividing velocity by the body length of the models (57 $\mathrm{cm})$. The time required to move one body length $\left(t_{b 1}\right)$ and half of one body length $\left(t_{b 1 / 2}\right)$ was computed for each model (1: Nautilus-like cruising thrust; 2: Nautilus-like cruising thrust scaled

Peer] reviewing PDF | (2021:04:60301:2:0:NEW 22 Jun 2021) 
1067 by the higher mantle cavity ratio of Sepia; 3: Nautilus-like peak thrust, coated and uncoated with 1068 hydrophobic silicone spray).

1069

1070 Table 5: Predator evasion potential of orthocone cephalopods using mostly extant predators as 1071 analogues. Dodges are considered successful (bold numbers) when the minimum distance 1072 required to start jetting (D) is less than the body length of a predator $\left(\mathrm{L}_{\mathrm{p}}\right)$ moving at some 1073 incident velocity $\left(\mathrm{V}_{\mathrm{p}}\right)$. The subscripts in $\mathrm{D}$ values refer to different thrust scenarios in the models 1074 (1: Nautilus-like cruising thrust; 2: Nautilus-like cruising thrust scaled by the higher mantle 1075 cavity ratio of Sepia; 3uc: Nautilus-like peak thrust with no coating; 3c: Nautilus-like peak 1076 thrust, coated in hydrophobic silicone spray). The velocity of Platecarpus (denoted by *) is only 1077 an estimate of metabolically optimal velocity (Motani, 2002), therefore critical/lunge velocity 1078 should be much higher. 


\section{Figure 1}

Construction of a physical, 3D-printed model of Baculites compressus from a virtual hydrostatic model.
A) Virtual model used to determine hydrostatic properties (modified from Peterman et al., 2019). B) Virtual model with simplified internal geometry that allows for 3D printing. The total model mass was manipulated to impart an upward buoyant force, simulating downward thrust. The total center of mass $(\mathrm{m})$ relative to the center of buoyancy $(\mathrm{b})$ was maintained with an adorally placed counterweight and various internal voids. C) Physical, 3D-printed model with tracking points placed at the distal ends of the arms and apex used for 3D motion tracking. 
A

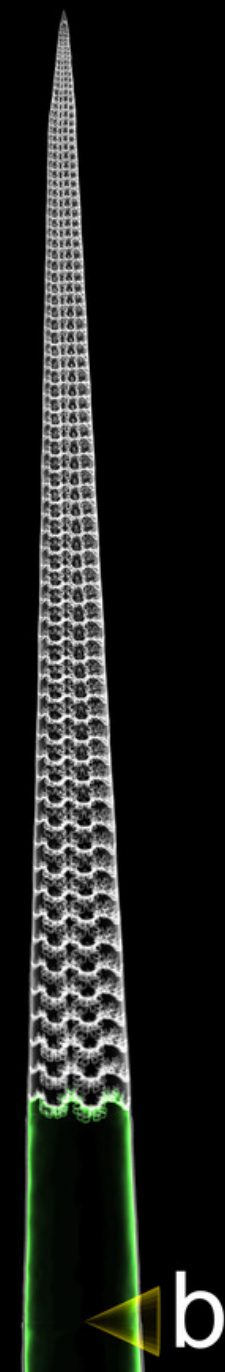

$\mathrm{m}$

Air-filled voids
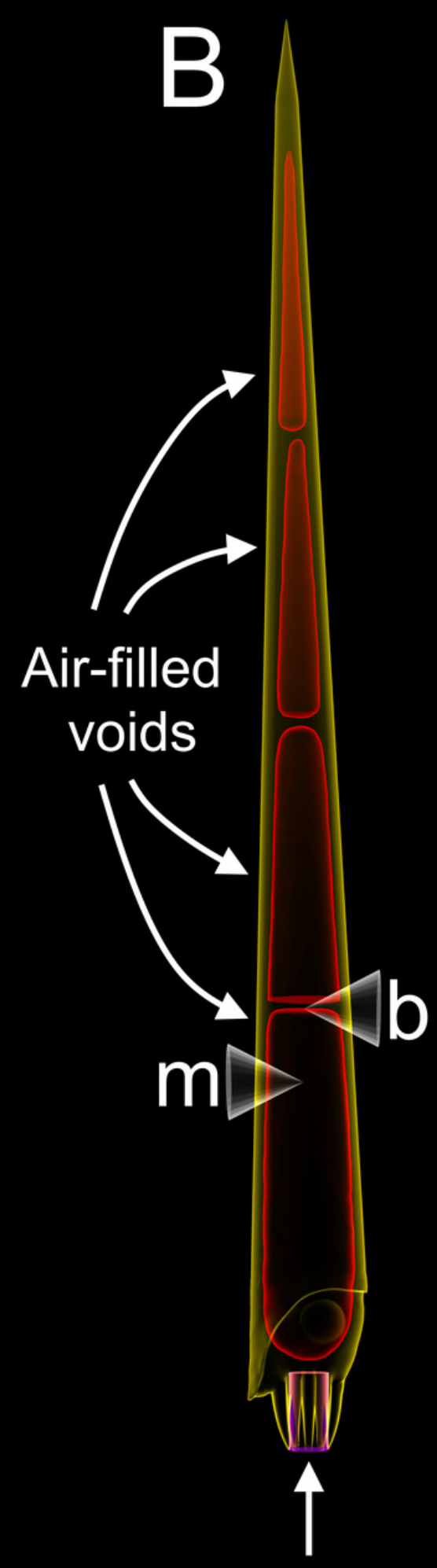

Bismuth counterweight
$5 \mathrm{~cm}$
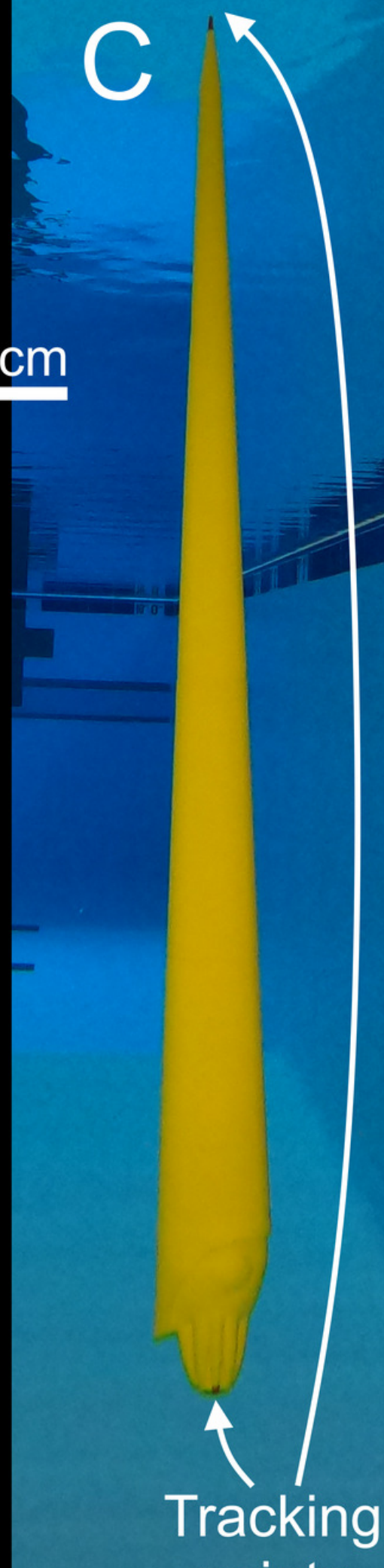

points 


\section{Figure 2}

Underwater camera rig used for 3D motion tracking.

A) Schematic of the camera rig relative to the model (yellow) and release mechanism (green). The rig was made strongly negatively buoyant with three steel counterweights at the ends (purple). The wireframe shapes radiating from the cameras denote the approximate field of view. B) Close-up view of waterproof camera and LED light with custom, 3D-printed attachments.

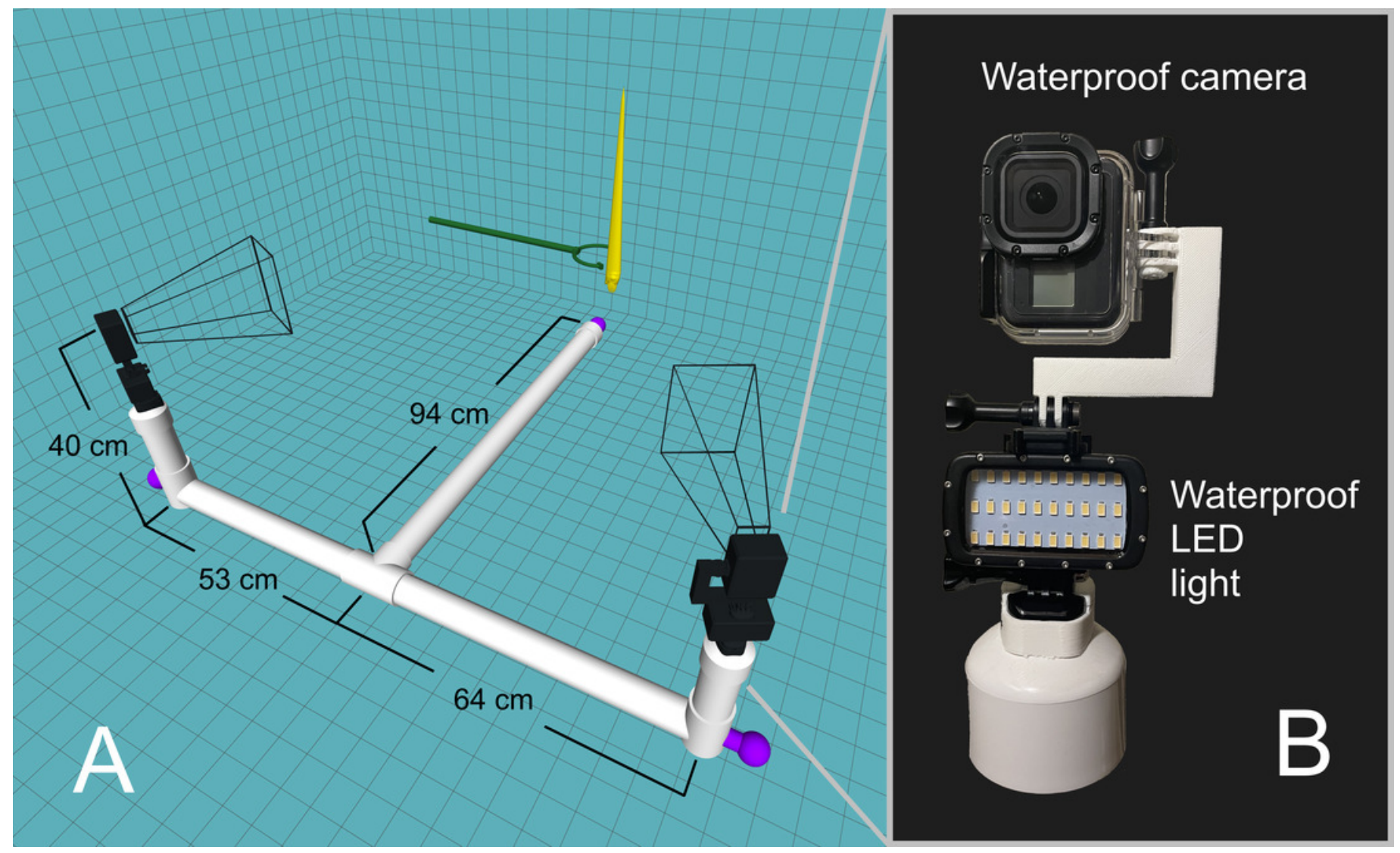


Figure 3

Three-dimensional positions from a common starting point for each model through time.

A) Scenario 1: Nautilus-like cruising thrust. B) Scenario 2: Nautilus-like cruising thrust scaled by the higher mantle cavity ratio of Sepia. C) Scenario 3: Nautilus-like peak thrust. D) Scenario 4: slightly negatively buoyant ( $0.26 \%$ of mass not relieved by buoyancy). 

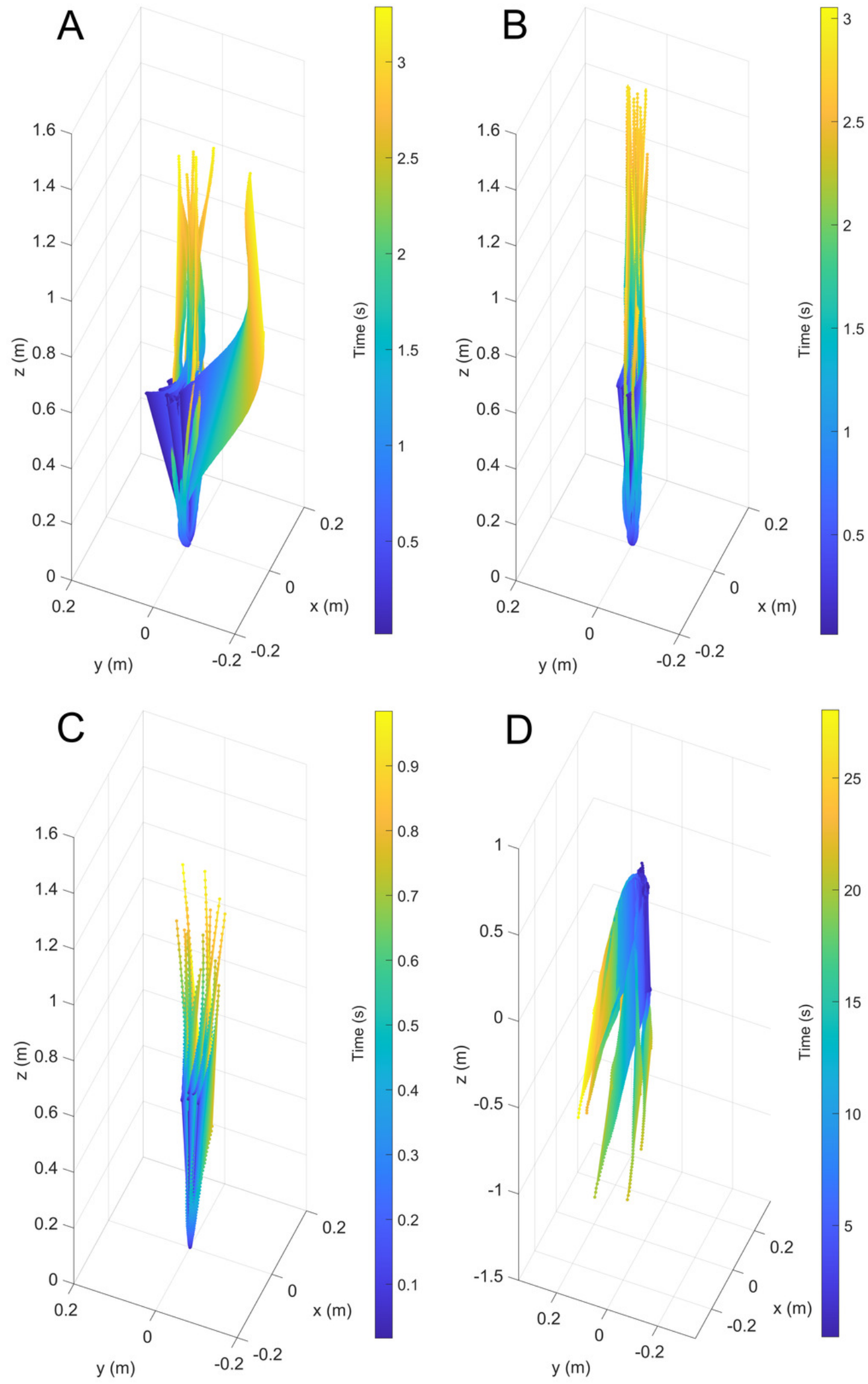

PeerJ reviewing PDF | (2021:04:60301:2:0:NEW 22 Jun 2021) 
Figure 4

Maximum displacement angle in any direction from the vertical axis through time.

Each trial is distinguished by color. A) Scenario 1: Nautilus-like cruising thrust. B) Scenario 2:

Nautilus-like cruising thrust scaled by the higher mantle cavity ratio of Sepia. C) Scenario 3:

Nautilus-like peak thrust. D) Scenario 4: slightly negatively buoyant ( $\sim 0.26 \%$ of mass not relieved by buoyancy).
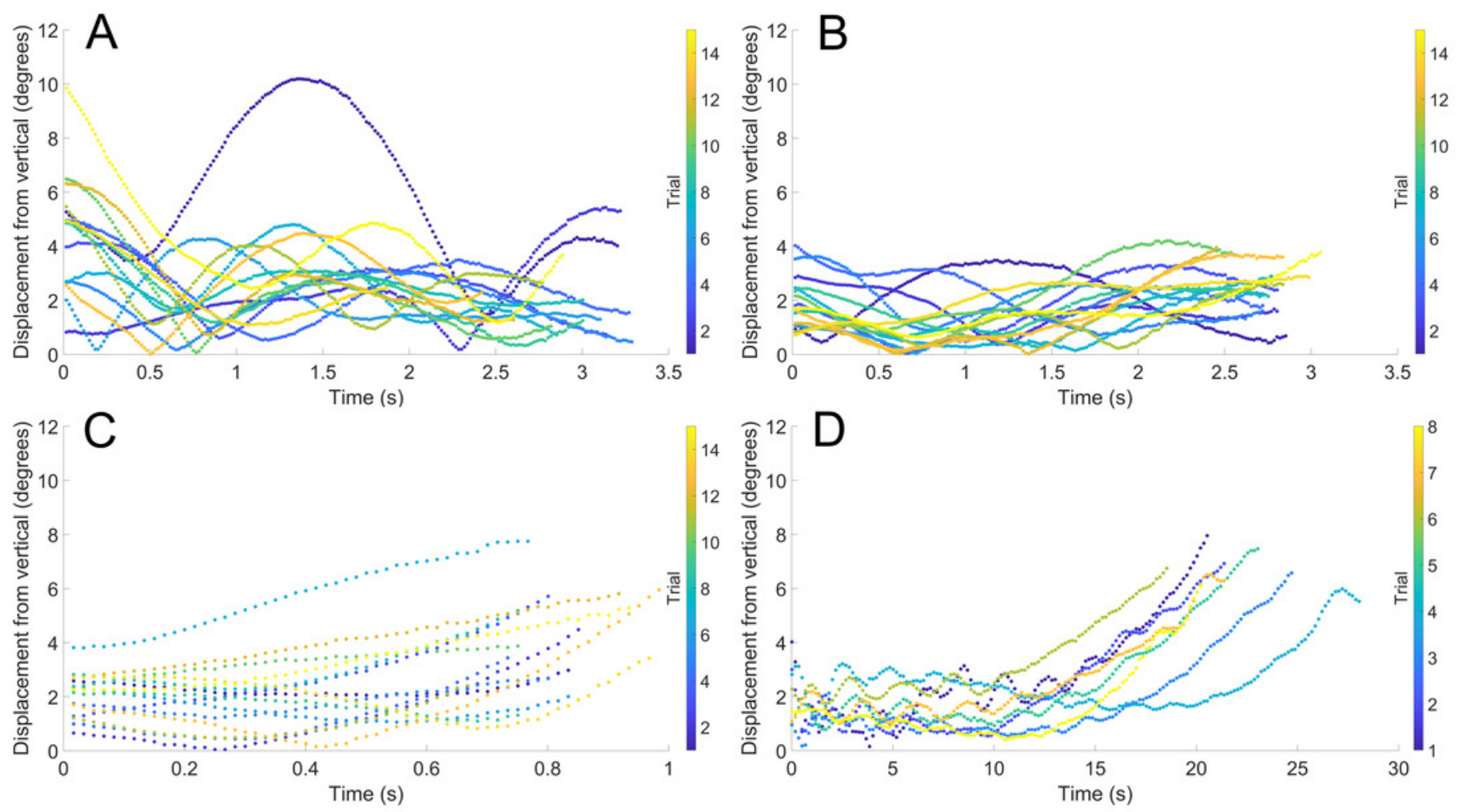
Figure 5

Velocity in the direction of movement as a function of time.

All trials are fit with an asymptote equation. A) Scenario 1: Nautilus-like cruising thrust. B)

Scenario 2: Nautilus-like cruising thrust scaled by the higher mantle cavity ratio of Sepia. C)

Scenario 3: Nautilus-like peak thrust. A hydrophobic coating was applied to the original model to compare the influence of surface texture and friction drag. D) Scenario 4: slightly negatively buoyant ( $\sim 0.26 \%$ of mass not relieved by buoyancy).
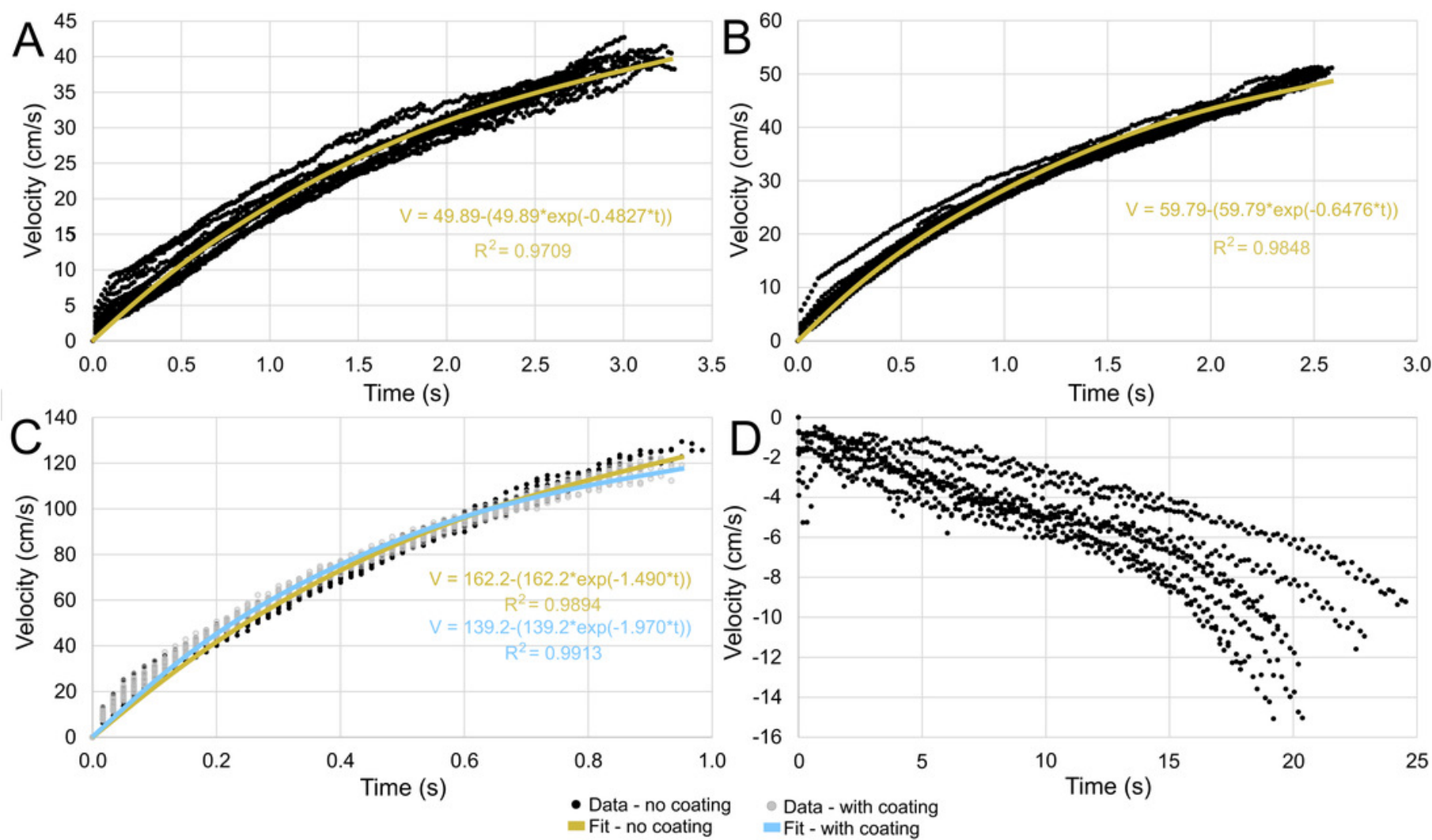


\section{Figure 6}

Diagram of vertical predator escape and related terms.

The time required to move one body length $\left(t_{b}\right)$ or half a body length $\left(t_{b / 2}\right)$ was computed for each velocity profile (V; Fig. 5). This time was multiplied by the velocity of various predators $\left(V_{p}\right)$ to compute the minimum distance required to start jetting (D). A dodge was considered successful if $D$ is less than the length of the predator $\left(L_{p}\right)$. The image of the mosasaur (Platecarpus) was created from the outline inferred by Lindgren et al. (2010).

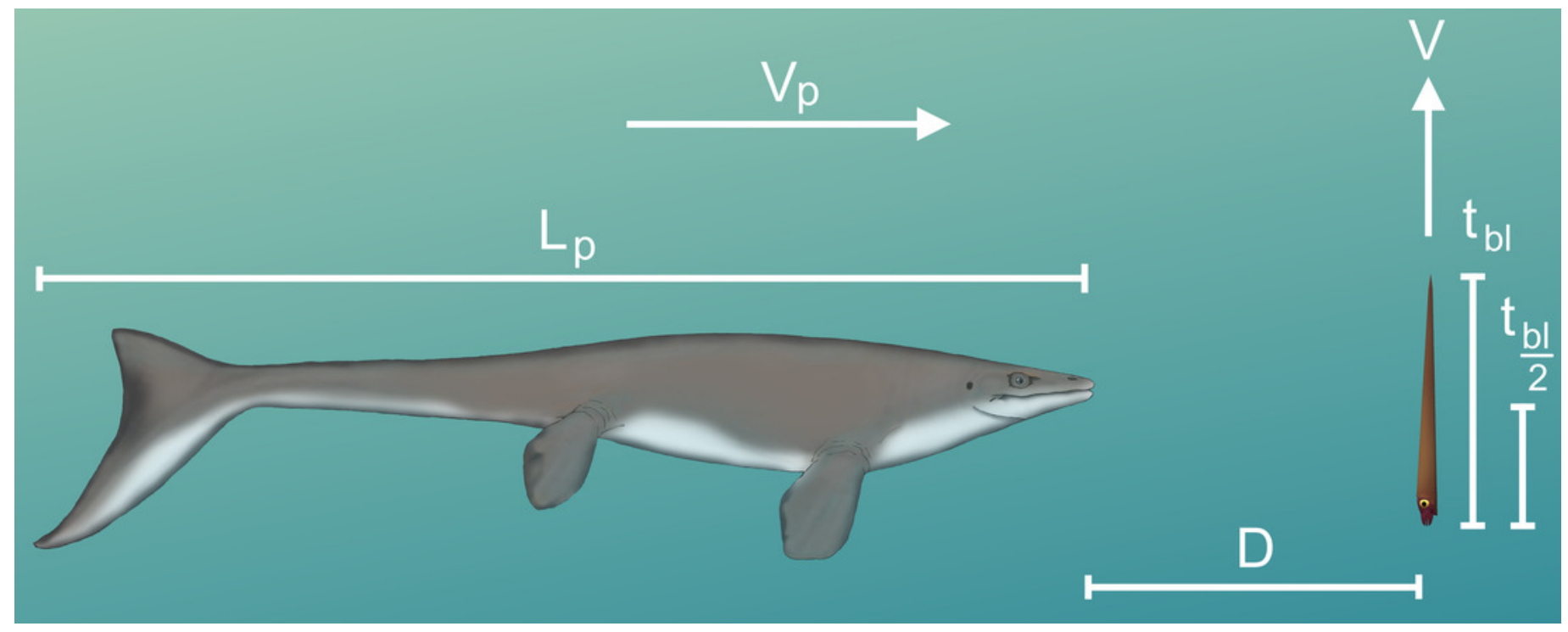




\section{Figure 7}

Scenarios involving successful dodging (A) and unsuccessful dodging (B).

The cruising predator first notices the prey (i), then begins to accelerate (ii). After closing in (iii), the predator makes its final lunge for the prey (iv). Cones surrounding the predator indicate hypothetical turning radiuses. For a successful dodge, the orthocone cephalopod must wait until the last possible moment or else the incoming predator could adjust its vertical trajectory. The image of the mosasaur (Platecarpus) was created from the outline inferred by Lindgren et al. (2010).

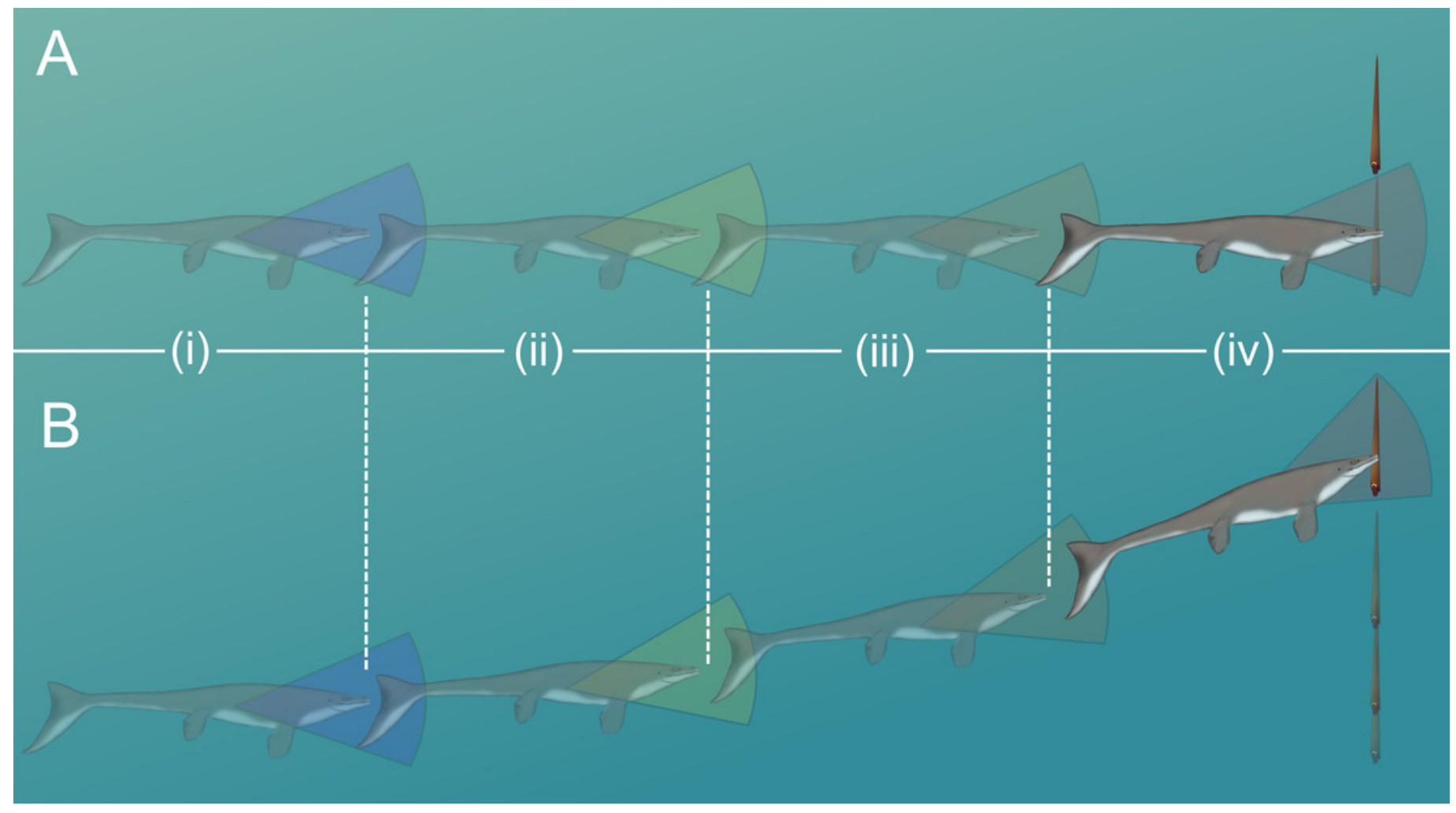




\section{Table $\mathbf{1}$ (on next page)}

Model centers of mass and buoyancy.

Local centers of mass for the model components (PLA plastic and bismuth counterweight), and total centers of mass and buoyancy for each model (1: Nautilus-like cruising thrust; 2 : Nautilus-like cruising thrust scaled by the higher mantle cavity ratio of Sepia; 3: Nautilus-like peak thrust; 4: Slightly negatively buoyant). Only the $x$ and $z$ values are reported because the virtual model is perfectly symmetrical. All coordinates are measured relative to the same arbitrary datum (located in the center of the aperture). 


\begin{tabular}{|c|c|c|c|c|c|c|c|c|}
\hline & \multicolumn{2}{|c|}{ PLA } & \multicolumn{2}{c|}{ Bismuth } & \multicolumn{2}{c|}{$\begin{array}{c}\text { Total center of } \\
\text { mass }\end{array}$} & \multicolumn{2}{c|}{$\begin{array}{c}\text { Center of } \\
\text { buoyancy }\end{array}$} \\
\hline $\begin{array}{c}\text { Baculite } \\
\text { model }\end{array}$ & $\begin{array}{c}\mathrm{x} \\
(\mathrm{mm})\end{array}$ & $\mathrm{z}(\mathrm{mm})$ & $\mathrm{x}(\mathrm{mm})$ & $\mathrm{z}(\mathrm{mm})$ & $\mathrm{x}(\mathrm{mm})$ & $\mathrm{z}(\mathrm{mm})$ & $\mathrm{x}(\mathrm{mm})$ & $\mathrm{z}(\mathrm{mm})$ \\
\hline 1 & -2.410 & 130.020 & -0.032 & -52.279 & -1.810 & 84.070 & -1.958 & 114.191 \\
\hline 2 & -2.375 & 119.742 & 0.439 & -57.934 & -1.810 & 84.070 & -1.958 & 114.191 \\
\hline 3 & -2.052 & 100.828 & 0.245 & -58.616 & -1.810 & 84.070 & -1.958 & 114.191 \\
\hline 4 & -1.767 & 101.472 & -2.366 & -57.998 & -1.810 & 84.070 & -1.958 & 114.191 \\
\hline
\end{tabular}

1 


\section{Table 2 (on next page)}

Masses (m) and volumes (V) for the virtual and physical model components.

1: Nautilus-like cruising thrust; 2: Nautilus-like cruising thrust scaled by the higher mantle cavity ratio of Sepia; 3: Nautilus-like peak thrust; 4: Slightly negatively buoyant. PLA = 3D printed plastic; $\mathrm{Bi}=$ bismuth counterweight; $w d=$ water displaced; Mass def. = mass deficiency required to impart the computed buoyant forces (Table 3); glue $=$ the cyanoacrylate glue used to secure each counterweight. The residual mass in the negatively buoyant experiment (denoted with *) was not weighed, but rather its volume was inserted into the model with a syringe $\left(\sim 0.5 \mathrm{~cm}^{3}\right)$. 


\begin{tabular}{|c|c|c|c|c|c|c|c|c|c|c|c|c|c|}
\hline \multirow[b]{2}{*}{$\begin{array}{c}\text { Baculite } \\
\text { model }\end{array}$} & \multicolumn{7}{|c|}{ Virtual } & \multicolumn{6}{|c|}{ Physical } \\
\hline & $\begin{array}{l}V_{\text {PLA }} \\
\left(\mathrm{cm}^{3}\right)\end{array}$ & $\begin{array}{c}\mathrm{m}_{\text {PLA }} \\
(\mathrm{g})\end{array}$ & $\begin{array}{l}\mathrm{V}_{\mathrm{Bi}} \\
\left(\mathrm{cm}^{3}\right)\end{array}$ & $\begin{array}{c}\mathrm{m}_{\mathrm{Bi}} \\
(\mathrm{g})\end{array}$ & $\begin{array}{r}\mathrm{m}_{\mathrm{wd}} \\
(\mathrm{g})\end{array}$ & $\begin{array}{c}\mathrm{m}_{\text {total }} \\
(\mathrm{g})\end{array}$ & $\begin{array}{l}\text { Mass } \\
\text { def. }(\mathrm{g})\end{array}$ & $\begin{array}{c}\mathrm{m}_{\text {PLA }} \\
(\mathrm{g})\end{array}$ & $\begin{array}{c}\mathrm{m}_{\mathrm{Bi}} \\
(\mathrm{g})\end{array}$ & $\begin{array}{c}\mathrm{m}_{\text {glue }} \\
(\mathrm{g})\end{array}$ & $\begin{array}{r}\mathrm{m}_{\mathrm{wd}} \\
(\mathrm{g})\end{array}$ & $\begin{array}{c}\mathrm{m}_{\text {total }} \\
(\mathrm{g})\end{array}$ & $\begin{array}{c}\text { Mass } \\
\text { def. (g) }\end{array}$ \\
\hline 1 & 124.319 & 155.275 & 5.651 & 52.490 & 212.209 & 207.765 & 4.444 & 157.875 & 49.737 & 0.101 & 212.209 & 207.713 & 4.496 \\
\hline 2 & 130.978 & 163.592 & 4.437 & 41.211 & 212.209 & 204.803 & 7.406 & 162.205 & 42.518 & 0.207 & 212.209 & 204.930 & 7.280 \\
\hline 3 & 126.935 & 158.542 & 2.018 & 18.745 & 212.209 & 177.287 & 34.922 & 158.529 & 18.612 & 0.355 & 212.209 & 177.496 & 34.713 \\
\hline 4 & 152.102 & 189.975 & 2.453 & 22.789 & 212.209 & 212.764 & -0.555 & 187.063 & 24.875 & 0.206 & 212.209 & 212.144 & $-0.5^{*}$ \\
\hline
\end{tabular}




\section{Table 3 (on next page)}

Virtual and actual hydrostatic stabilities $\left(\mathrm{S}_{\mathrm{t}}\right)$ and thrusts $(\mathrm{F})$, and computed percent errors.

1: Nautilus-like cruising thrust; 2: Nautilus-like cruising thrust scaled by the higher mantle cavity ratio of Sepia; 3: Nautilus-like peak thrust; 4: Slightly negatively buoyant. 


\begin{tabular}{|c|c|c|c|c|c|c|}
\hline $\begin{array}{c}\text { Baculite } \\
\text { model }\end{array}$ & $\begin{array}{c}\text { Virtual } \\
\mathrm{S}_{\mathrm{t}}\end{array}$ & $\begin{array}{c}\text { Actual } \\
\mathrm{S}_{\mathrm{t}}\end{array}$ & $\begin{array}{c}\text { St error } \\
(\%)\end{array}$ & $\begin{array}{c}\text { Target } \\
\mathrm{F}(\mathrm{N})\end{array}$ & $\begin{array}{c}\text { Actual } \\
\mathrm{F}(\mathrm{N})\end{array}$ & $\begin{array}{c}\text { Thrust } \\
\text { error } \\
(\%)\end{array}$ \\
\hline 1 & 0.505 & 0.492 & -2.57 & 0.0436 & 0.0441 & 1.17 \\
\hline 2 & 0.505 & 0.499 & -1.19 & 0.0727 & 0.0714 & -1.77 \\
\hline 3 & 0.505 & 0.483 & -4.36 & 0.3426 & 0.3405 & -0.60 \\
\hline 4 & 0.505 & 0.454 & -10.10 & -0.0054 & -0.0049 & -9.42 \\
\hline
\end{tabular}

1 


\section{Table 4 (on next page)}

Velocities, travel times, and asymptote equation coefficients.

Uncertainty reflects bounds of $95 \%$ confidence intervals. The asymptotic velocity (in $\mathrm{cm} / \mathrm{s}$ ) is predicted by coefficient "a" of Equation 6. Coefficient "b" governs the slope. The maximum body lengths per second (Max. bl/s) were computed by dividing velocity by the body length of the models $(57 \mathrm{~cm})$. The time required to move one body length $\left(t_{b l}\right)$ and half of one body length $\left(t_{b / 2}\right)$ was computed for each model (1: Nautilus-like cruising thrust; 2 : Nautilus-like cruising thrust scaled by the higher mantle cavity ratio of Sepia; 3: Nautilus-like peak thrust, coated and uncoated with hydrophobic silicone spray). 


\begin{tabular}{|c|c|c|c|c|c|}
\hline Model & $\begin{array}{c}\mathbf{a}(\mathbf{V} \text { asymptote } \\
\mathbf{c m} / \mathbf{s})\end{array}$ & $\mathbf{b}$ & Max. bl/s & $\mathbf{t}_{\mathbf{b l} \mathbf{~}}(\mathbf{s})$ & $\mathbf{t}_{\mathbf{b} / 2}(\mathbf{s})$ \\
\hline $\mathbf{1}$ & $49.89 \pm 0.72$ & $0.4827 \pm 0.0116$ & $0.875 \pm 0.013$ & $2.633 \pm 0.048$ & $1.755 \pm 0.032$ \\
\hline $\mathbf{2}$ & $59.79 \pm 0.58$ & $0.6476 \pm 0.0111$ & $1.049 \pm 0.010$ & $2.101 \pm 0.026$ & $1.395 \pm 0.018$ \\
\hline $\mathbf{3}$ (uncoated) & $162.2 \pm 3.10$ & $1.490 \pm 0.045$ & $2.846 \pm 0.054$ & $0.826 \pm 0.019$ & $0.552 \pm 0.013$ \\
\hline $\mathbf{3}$ (coated) & $139.2 \pm 1.50$ & $1.970 \pm 0.040$ & $2.442 \pm 0.026$ & $0.815 \pm 0.012$ & $0.535 \pm 0.008$ \\
\hline
\end{tabular}

1 


\section{Table 5 (on next page)}

Predator evasion potential of orthocone cephalopods using mostly extant predators as analogues.

Dodges are considered successful (bold numbers) when the minimum distance required to start jetting (D) is less than the body length of a predator $\left(L_{p}\right)$ moving at some incident velocity $\left(V_{p}\right)$. The subscripts in $D$ values refer to different thrust scenarios in the models ( 1 : Nautilus-like cruising thrust; 2: Nautilus-like cruising thrust scaled by the higher mantle cavity ratio of Sepia; 3uc: Nautilus-like peak thrust with no coating; 3c: Nautilus-like peak thrust, coated in hydrophobic silicone spray). The velocity of Platecarpus (denoted by *) is only an estimate of metabolically optimal velocity (Motani, 2002), therefore critical/lunge velocity should be much higher. 


\begin{tabular}{|c|c|c|c|c|c|c|c|c|c|c|c|c|}
\hline \multirow[b]{2}{*}{ Species } & \multirow[b]{2}{*}{ Common name } & \multirow[b]{2}{*}{$\begin{array}{l}\mathbf{L}_{p} \\
(\mathrm{~m})\end{array}$} & \multirow[b]{2}{*}{$\begin{array}{c}\mathbf{V}_{p} \\
(\mathbf{m} / \mathbf{s})\end{array}$} & \multirow[b]{2}{*}{ Reference } & \multicolumn{4}{|c|}{ Moving one body length $(57 \mathrm{~cm})$} & \multicolumn{4}{|c|}{$\begin{array}{c}\text { Moving 1/2 body length (28.5 } \\
\text { cm) }\end{array}$} \\
\hline & & & & & $\begin{array}{c}\mathbf{D}_{1} \\
(\mathbf{m})\end{array}$ & $\begin{array}{c}\mathbf{D}_{2} \\
(\mathbf{m})\end{array}$ & $\begin{array}{l}\mathbf{D}_{3 \mathrm{uc}} \\
(\mathbf{m})\end{array}$ & $\begin{array}{l}\mathbf{D}_{3 \mathrm{c}} \\
(\mathbf{m})\end{array}$ & $\begin{array}{l}\mathbf{D}_{1} \\
(\mathbf{m})\end{array}$ & $\begin{array}{l}\mathbf{D}_{2} \\
(\mathbf{m})\end{array}$ & $\begin{array}{l}\mathbf{D}_{3 \mathrm{uc}} \\
(\mathbf{m})\end{array}$ & $\begin{array}{l}\mathbf{D}_{3 \mathrm{c}} \\
(\mathbf{m})\end{array}$ \\
\hline Platecarpus & Mosasaur & 4 & $0.38 *$ & Motani, 2002 & 1.00 & 0.80 & 0.31 & 0.31 & 0.67 & 0.53 & 0.21 & 0.20 \\
\hline $\begin{array}{l}\text { Megaptera } \\
\text { novaeangliae }\end{array}$ & Humpback whale & 12.7 & 5 & $\begin{array}{l}\text { Segre et al., } \\
2020\end{array}$ & 13.17 & 10.51 & 4.13 & 4.08 & 8.78 & 6.98 & 2.76 & 2.68 \\
\hline $\begin{array}{c}\text { Crocodylus } \\
\text { porosus }\end{array}$ & $\begin{array}{l}\text { Saltwater } \\
\text { crocodile }\end{array}$ & 5 & 8 & $\begin{array}{l}\text { Benga et al., } \\
2010\end{array}$ & 21.06 & 16.81 & 6.61 & 6.52 & 14.04 & 11.16 & 4.42 & 4.28 \\
\hline $\begin{array}{l}\text { Delphinus } \\
\text { delphis }\end{array}$ & $\begin{array}{c}\text { Short-beaked } \\
\text { common dolphin }\end{array}$ & 1.8 & 8 & $\begin{array}{l}\text { Tanaka et al., } \\
2019 \\
\end{array}$ & 21.06 & 16.81 & 6.61 & 6.52 & 14.04 & 11.16 & 4.42 & 4.28 \\
\hline $\begin{array}{c}\text { Stenella } \\
\text { attenuata }\end{array}$ & $\begin{array}{c}\text { Pantropical } \\
\text { spotted dolphin }\end{array}$ & 1.86 & 11 & $\begin{array}{c}\text { Tanaka et al., } \\
2019 \\
\end{array}$ & 28.96 & 23.11 & 9.09 & 8.97 & 19.31 & 15.35 & 6.07 & 5.89 \\
\hline Isurus oxyrincus & $\begin{array}{l}\text { Shortfin mako } \\
\text { shark }\end{array}$ & 2.1 & 19 & $\begin{array}{l}\text { Fernandez-Waid } \\
\text { et al., } 2019\end{array}$ & 50.03 & 39.92 & 15.69 & 15.49 & 33.35 & 26.51 & 10.49 & 10.17 \\
\hline
\end{tabular}

